\title{
Realis mood, focus, and existential closure in Tundra Yukaghir
}

\author{
Dejan Matić $^{a, *}$, Irina Nikolaeva ${ }^{b}$ \\ a Syntax, Typology, and Information Structure Group, Max-Planck-Institute for Psycholinguistics, Wundtlaan 1, 6525 XD Nijmegen, \\ The Netherlands \\ ${ }^{\mathrm{b}}$ Department of Linguistics, School of Oriental and African Studies, University of London, Thornhaugh Street, Russell Square, \\ London WC1H OXG, United Kingdom
}

Received 3 June 2013; received in revised form 25 July 2014; accepted 26 July 2014

Available online

\begin{abstract}
The nature and the typological validity of the categories 'realis' and 'irrealis' has been a matter of intensive debate. In this paper we analyse the realis/irrealis dichotomy in Tundra Yukaghir (isolate, north-eastern Siberia), and show that in this language realis is associated with a meaningful contribution, namely, existential quantification over events. This contribution must be expressed overtly by a combination of syntactic and prosodic means. Irrealis is the default category: the clause is interpreted as irrealis in the absence of the marker of realis. This implies that the relevant typological question may turn out to be the semantics of realis, rather than irrealis. We further argue that the Tundra Yukaghir realis is a hybrid category composed of elements from different domains (information structure, lexical semantics, and quantification) unified at the level of interpretation via pragmatic enrichment. The concept of notional mood must therefore be expanded to include moods which come about in interpretation and do not constitute a discrete denotation.
\end{abstract}

(C) 2014 Elsevier B.V. All rights reserved.

Keywords: Notional mood; Realis; Irrealis; Focus; Information structure; Event semantics; Tundra Yukaghir

\section{Introduction}

The terms 'realis' and 'irrealis' are often used as semantic categories: they refer to two opposite values of the functional domain loosely characterised in terms of 'reality status' or 'actualization'. This may be realised differently in different languages, either by verbal inflection ('grammatical mood') or non-inflectional means such as free-standing particles and adverbs, modal verbs or verb-like items, constituent order, etc. A convenient label for this broader notion of mood that has gained popularity in the past decade is notional mood. Notional mood describes a wide range of grammatical patterns associated with mood-like meanings, the use of which can be explained on the basis of the theory that is used to explain grammatical moods (Portner, 1999, 2011). This is how we will be using the term 'mood' throughout this paper.

Abbreviations: ACC, accusative; AF, transitive subject focus; ATTR, attributive; AUG, augmentative; CJT, conjectural; COM, comitative; COND, conditional; DAT, dative; DES, desiderative; DS, different subject; EV, evidential; EX, existential; NP/FCl, negative polarity/free choice item; FOC, focus; FUT, future; IMP, imperative; INCH, inchoative; INS, instrumental; INTERR, interrogative; INTJ, interjection; INTR, intransitive; IPF, imperfective; HAB, habitual; HORT, hortative; HYP, hypothetical; LOC, locative; NEC, necessitative; NEG, negative; NEUT, neutral; NLZR, nominaliser; O, object; OF, object focus; 0, epenthetic vowel; PF, perfective; PL, plural; POSS, possessive; POT, potential; PRP, proprietive; PTC, participle; PTL, particle; S, subject; SF, intransitive subject focus; SG, singular; SS, same subject; STAT, stative; TEMP, temporal; TR, transitive; $\mathrm{V}$, verb.

* Corresponding author. Tel.: +31 243521 187; fax: +31 243521213.

E-mail addresses: dejan.matic@mpi.nl, dejanmatic@hotmail.com (D. Matić), in3@soas.ac.uk (I. Nikolaeva). 
The question, however, is whether this notional understanding of the opposition between realis and irrealis is universally applicable. Some authors speak of the reality status as a cross-linguistic grammatical category in its own right (e.g. Foley and Van Valin, 1984; Van Valin and La Polla, 1997: 40ff; Elliott, 2000: 80). Its two values are characterised in terms of actualisation vs. non-actualisation of a given state of affairs. A proposition is said to be realis when it asserts that a state of affairs is an "actualised and certain fact of reality" (Elliott, 2000: 66). In contrast, irrealis implies that a state of affairs "belongs to the realm of the imagined or hypothetical, and as such it constitutes a potential or possible event but it is not an observable fact of reality" (Elliott, 2000: 67). This notion typically includes potential actualisations (epistemic, deontic and desiderativeintentional meanings) and non-actualisations (counterfactual and negative constructions, i.e. the realm of unrealised).

What remains unclear is whether there is one notional feature that lies in the centre of this distinction. Crosslinguistically, there is no one-to-one correspondence between the status of an eventuality and the use of realis or irrealis. Both categories are known to convey a wide array of meanings which differ greatly across languages, so that proposition types marked as realis in one language may be marked as irrealis in another. The fact that the contents of these categories are not comparable from language to language and that the same constructions seem to be able to express both realised and unrealised states of affairs (at least in the first approximation) has led some linguists to doubt the typological validity of the realis/irrealis distinction (see de Haan, 2012 and Mauri and Sansò, 2012a for recent overviews). For instance, Bybee et al. (1994: 236-40) and Bybee (1998) suggest that grammars do not make a consistent binary distinction related to reality status. Cristofaro (2012) argues that, although the notion of 'unrealised state of affairs' may be relevant in the sense that that it plays a role in determining the patterns of polyfunctionality for some linguistic constructions, there is no evidence that it forms a feature that is part of a speaker's linguistic knowledge at the synchronic level.

On the other hand, a number of researchers working on individual languages have argued that the realis/irrealis distinction does make a stable interpretive contribution, even though it may differ from one language to another and require a separate semantic definition for each. For instance, Verstraete (2005) suggests that the basis of the irrealis category in several non-Pama-Nyungan languages of Australia is the expression of potentiality. This is a robust core meaning which may trigger the implicature that the described event did not take place; that is, under certain conditions the basic semantics of potential actualisation is extended into the domain of non-actualisation (counterfactuality). McGregor and Wagner (2006) propose that in Nyulnyulan, too, the irrealis encodes a single core meaning, namely, the construal by the speaker of a situation as unreal, either in the actual world or some possible world. The potentiality meaning is not a semantic invariant associated with the category itself, but is accounted for by pragmatic inferences arising from the relevant speech act. It may then turn out to be impossible to provide a universal cross-linguistic definition of the realis/irrealis dichotomy. However, it can probably be conceptualised as a spectrum encompassing language-particular binary categories which stand in the family resemblance relation to one another. This seems to be the position shared by some typologically oriented studies that argue for the theoretical relevance of these notions (Givón, 1994; Mithun, 1995; Palmer, 2001).

In this paper we provide an analysis of the realis/irrealis dichotomy in Tundra Yukaghir (TY henceforth), a member of a small language family in north-eastern Siberia. This family additionally comprises Kolyma Yukaghir, at present nearly extinct (see Nikolaeva, 2000: 89 ff., 2006 on other extinct varieties), and may be distantly related to Uralic (Fortescue, 1998; Nikolaeva, 2000: 25ff., 2006, among others). TY is spoken in the villages of Andryushkino and Kolymskoe (the Lower Kolyma District of the Sakha Republic, Russia) by 63 speakers (according to the survey made by Dejan Matic and Cecilia Odé in 2010-11). The data used in this paper come from natural discourse, namely the texts collected by Dejan Matic in 2008-2012 and the texts published in Maslova (2001) and Kurilov (2005), as well as from elicitation.

We argue that the contrast between moods in TY has to do with existential quantification over events and is derived from different types of denotations via pragmatic enrichment. At the first glance, our analysis follows the non-universalist line of thought outlined above. It suggests that the opposition between the two categories is real, even though the dividing line is defined on a language-particular basis. That is, the TY realis does not mean exactly the same as, say, the realis in Nyulnyulan, but it is still a notional mood expressed by a mixture of morphological, prosodic and syntactic means. However, we go further than this: we argue that semantically, the TY realis is a hybrid category, composed of elements from different domains (information structure, lexical semantics, and quantification), but unified by a higher-level notion of existential closure of events in Davidson's (1967) sense. In order to describe the realis mood in TY, we will use the notional apparatus of event semantics. Events are spatio-temporal particulars that occupy a certain space at a certain time. We take it that predicates have an event argument, a variable representing the event they describe. ${ }^{1}$ To guarantee that the sentence denotes a proposition, some kind of quantification over events is necessary. This is achieved by means of an

\footnotetext{
${ }^{1}$ We bypass some controversial issues of event semantics that are irrelevant for our purposes. In particular, we are agnostic as to the syntactic status of the event argument (see Beck and von Stechow, 2006 for a discussion). The exact nature of the relationship between this argument and the predicate is immaterial for our purpose, too: our analysis is compatible both with the classical Davidsonian account, according to which the event argument is merely one of the arguments of the predicate, and with Neo-Davidsonian semantics, in which the event argument is the only proper argument (a good overview of this issue is found in Maienborn, 2011).
} 
existential quantifier which scopes over the event variable. The existential quantification over the event introduces existential closure over the whole proposition and unselectively binds all variables within it. This is illustrated in (1).

$$
\begin{aligned}
& \text { Peter reads a newspaper in the café. } \\
& \exists \text { e [READ(Peter, newspaper, e) \& IN (e, the café)] }
\end{aligned}
$$

We will argue that the existential closure of the proposition is one of the necessary conditions for a sentence to be interpreted as realis in TY. In particular, the unselective nature of the closure accounts for the fact that those expressions which cannot introduce discourse referents due to their referential weakness or for some other reason cannot occur in realis clauses.

However, existential closure is not a sufficient condition for a realis interpretation. Two important aspects of events are unaccounted for by the formula in (1). First, events occur in a particular world. This obviously relates the realis meaning in TY to verbal mood. In this paper, we adopt the standard approach to modal semantics as developed by Kratzer (1991, 2012). There are two important notions in this approach: the modal base, i.e. the set of possible worlds relevant for the interpretation of the sentence, and the ordering source, which ranks the worlds according to some parameter so as to establish an ordering relevant for the truth of the proposition. In order to account for some quirks of modal marking in TY, we will enrich this model with the notion of the speaker's contextual commitment to the modal base/ordering source, which implies the readiness of the speaker to argue rationally for the optimal status of the event given the ordering source (Portner and Rubinstein, 2012). A realis clause in TY is specified with respect to all three of these parameters. The world in which the event denoted by the realis clause takes place is the actual world; if possible worlds are involved, what counts as the actual world has to belong to the set of best worlds according to the ordering source, and the speaker has to be contextually committed to this world.

Second, events exist in time and place, i.e. in specific sections of the world. In order for an event to be existentially quantified, a reference to the specific spatio-temporal section of the world in which it unfolds, that is, the situation in the sense of Austin (1950), must be established (Krifka, 1989: 90). We take it that situations are presupposed and temporally delimited. The temporal notions we use to capture this idea stem from Klein (1994). In particular, we make use of the distinction between topic time (TT) and event time (ET). The latter refers to the temporal extension of an event, the former to the segment of time about which the speaker makes a claim. In TY, realis events must take place within the topic time, i.e. ET < TT. The notion of topic time is thus crucial in delimiting the situation within which the event takes place. This is because the speaker can commit herself only to the claim that the event exists in the segment of time about which the assertion is made, i.e. within TT. Anything beyond TT is beyond the scope of the claim with realis interpretation. The full specification of a realis clause in TY, including existential binding and the world and time/situation restrictions, is given in (2).

A clause in TY is realis if its logical form is

$\exists e\left[P(e) \& \operatorname{TIME}(e) \subseteq \mathrm{t}^{\prime} \& \mathrm{e}<\mathrm{w}\right]$

and it is evaluated with respect to topic time TT and world w-actual, such that

(a) $\mathrm{t}^{\prime} \leq \mathrm{TT}$

(b) $\mathrm{w}$ is the actual world or highest ranking world according to the modal base and ordering source

(c) the speaker is contextually committed to the modal base and ordering source.

This reads as follows: a clause in TY is realis if its logical form is such that it denotes an event that corresponds to the description given by the proposition and this event extends over a subinterval of topic time and takes place in the actual world or in the preferred world to which the speaker is committed.

Existential closure (and its additional semantic specifications) can have different sources in different languages, which range from aspectual and temporal operators, verb meaning itself, valence-increasing morphology and covert operators to overt existential quantifiers (Zimmermann, 2007). In other words, a sentence that satisfies the conditions contained in (2) can do so by virtue of its being perfective, or through the lexical meaning of the predicate, or it can contain an overt existential quantifier. We will argue that in TY (2) is a type of interpretation which can be reached from (at least) two different sources. The first source is an explicit existential quantifier, the particle $m ə(r)=$. This particle presents a longstanding descriptive problem in TY syntax: it has been analysed alternately as a focus, declarative or polarity marker. We propose that the use of the existential particle $m ə(r)=$ is sensitive to possible world semantics and aspect, but also to the commitment of the speaker to the truth of the proposition.

The second possible source of existential closure in TY is information structure, whose effects come about both through explicit bipartition of the proposition into focus and background and through constructions with inherently focused elements (the latter include adverbial modifiers and loosely incorporated objects in TY). In order to capture the information-structural effects of realis interpretation, we will use a simplified version of Rooth's Alternative Semantics 
(Rooth, 1992) and treat focus as the element of the sentence that carries the main assertion via evocation of alternatives. Our approach to focus differs from that of Rooth (1999) in that we assume that focus is a soft presupposition trigger in the sense of Abusch (2010), i.e. the background to focus is routinely presupposed unless there is evidence to the contrary (cf. also Geurts and van der Sandt, 2004). This default presuppositional interpretation of the event within which one of the elements is treated as focused leads to the default existential closure of the proposition and has the same effect as the overt existential quantifier. As a result, the sentence is understood as fulfilling the conditions given in (2).

This analysis explains the complementary distribution of focus marking and the existential quantifier $m ə(r)=$, as well as their similar properties in relation to mood. Since $m ə(r)=$ and different types of non-verbal foci are mutually exclusive, they might appear to form a kind of paradigm whose denotation is something close to (2). However, we show that this is not the case. The only feature that the diverse structures that make up the realis mood in TY share is that they, starting off from different source meanings, entail the existence of an event within the topic time. They are neither unified at the level of structure nor at the level of encoded meaning: the existential quantifier encodes existence by virtue of its denotation, while focus entails it via inference. The modal meaning then comes about through interpretation associated with more fundamental semantic operations. The corollary of this analysis is that a modal category need not be based on Platonic essences: the TY realis is a set of interpretive effects which arise from different sources. If the notional mood is something that can be explained on the basis of the theory that is used to explain grammatical moods, as Portner suggests, the catalogue of notional moods must be expanded to include this specific type of expression: moods that come about in interpretation.

The paper is structured as follows. In Section 2 we introduce the realis/irrealis distinction in TY and describe its most important formal characteristics. Section 3 analyses the formal and semantic properties of foci and related expressions, while Section 4 is devoted to the form and meaning of the particle $m ə(r)=$; this leads to a more precise definition of the TY realis and contributes to a better understanding of the TY focus system. In Section 5 we discuss the relation between the realis mood, existential quantification and focus. In the final section we summarise our findings and discuss the consequences of our analysis for the general theory of linguistic categorisation.

\section{Realis and irrealis in Tundra Yukaghir}

TY is a typical SOV language, with a fairly rigid verb-final structure in main/independent clauses; the same rigid headfinal pattern is evident in noun phrases, postpositional phrases and non-finite dependent clauses. The language is known in the typological literature for its intricate system of morphological focus marking ${ }^{2}$; however, the structural opposition between realis and irrealis described in this section has never been discussed in the earlier work.

\subsection{Mood and basic clause structure}

TY has a number of morphologically marked moods, which we label imperative (3a), potential (the suffix -mori, possible future situations) (3b), necessitative (the complex suffix -morawńə, deontic modality) (3c), conditional (the proclitic ət=, possible or desirable situations) (3d), desiderative (the suffix -lbuń, desired situations) (3e), and conjectural (the complex suffix -l'əltə, probable situations) (3f). There is no dedicated morphological marker of realis. The unmarked verbal form can have quite different readings with respect to the reality status of the proposition, from the indicative-like 'realis' reading to various directive (4a) or hypothetical meanings (4b). In other words, the lack of modal inflections on the verb is not a marker of the 'realis mood' either.

$\begin{array}{ll}\text { a. } & \text { anńə-k! } \\ \text { b. } & \text { kewej-mori-jəク } \\ \text { c. } & \text { kuder-o:I-morawńə-j } \\ \text { d. } & \text { ət=jaba-j } \\ \text { e. } & \text { law-lbuń-i } \\ \text { f. } & \text { mira:-l'əltə-jli }\end{array}$

(4)
a. jo:yačəli
b. mid'ek med'i-m

'Speak!'

'I would/could leave.'

'He must put (it).'

'He would die.'

'He wants to drink.'

'We might walk.'

'Let's stop!'

'He might take (it).'

\footnotetext{
${ }^{2}$ The primary description of this system can be found in Krejnovič (1958, 1982); for more details see Comrie (1992), Fortescue (1996), and Maslova $(2003,2005,2006)$.
} 
On the basis of these data it appears that realis is not a category of TY grammar. However, it is a relevant notion in TY. As indicated above, realis assertions share one notional property: they entail the existence of an event in the topic time. The distinction between realis and irrealis is reflected in the clause structure. In a sense, realis clauses are marked, as they impose an additional formal constraint: they must contain a syntactic element that signals the realis interpretation. The minimal structure of a realis clause is as follows:

$$
\begin{array}{ll}
\text { Realis clause: } & X+V \\
\text { where } X \text { is } & \text { (i) a non-verbal focus element, or } \\
& \text { (ii) a verb modifier, or } \\
& \text { (iii) the verbal particle } m \partial(r)=
\end{array}
$$

Some types of irrealis clauses can contain non-verbal foci and verb modifiers, but this happens rather infrequently, and is not required for the grammaticality of the clause (see Section 5.2). The particle mə(r)= never occurs in irrealis.

The items making up class $X$ above are rather heterogeneous. The first subclass includes nominal foci, which come in three basic forms. When the focus falls on S or O, it is indicated with the marker $-l \partial(\eta) /-(\partial) k^{3}{ }^{3}$ The verb only agrees with the subject ( $\mathrm{S}$ or A), but the actual exponence of agreement depends on which argument is focused, $\mathrm{S}$ or $\mathrm{O}$. This is glossed as OF and SF for 'object focus' and 'intransitive subject focus', respectively.

(6) peldude: qad'ir mət-in a:ri:-lə tadi:-mələ

old.man PTL I-DAT gun-FOC give3-OF.3

'The old man gave me a GUN.'

\section{(7) mət-ek werwə-I}

I-FOC be.strong-SF

'I am the one who is strong.'

Focus on A is not morphologically marked, and the verb shows no agreement in this case $(\varnothing$, glossed as AF for 'transitive subject focus').

(8) tun a:ri: mot nu:- $\varnothing$

this gun $I$ find-AF

'It is me who found this gun.'

The focus on oblique arguments/adjuncts receives no special morphological marking either. The verb agrees with the subject ( $\mathrm{S}$ or $\mathrm{A}$ ) and stands in the so-called 'neutral' agreement form (NEUT in the glosses).
tun qul'arqa: ma:rqə-n sa:I-ya sayanə-j,
əl=lukunburəbə-ya
this seagull one-ATTR tree-LOC sit-NEUT.INTR.3SG NEG=earth-LOC
'This seagull is sitting on a tree, not on the earth.'

The second subclass is comprised of what we call verb modifiers. We borrow this term from studies of Hungarian clause structure, where it refers to the class of expressions including aspectual prefixes, bare nominals and directives, which compete with the focus phrase for the immediately preverbal position (Koopman and Szabolcsi, 2000: 19ff; Wedgwood, 2005: 81ff). In TY, verb modifiers include most manner adverbials, such as e.g. amutnəク 'well' and amdur 'quickly', and non-referential nouns, occurring both in idiomatic verb-noun complexes, e.g. jayun mojorńə- 'snore' (lit. 'nose-sound'), čundə(lə) gudiči:- 'think' (lit. 'thought-put'), nonyələ law- 'smoke' (lit. 'tobacco-drink'), and in more compositional verb-noun combinations, e.g. lawjələ men- 'fetch water' and ča:jlə law- 'drink tea'.

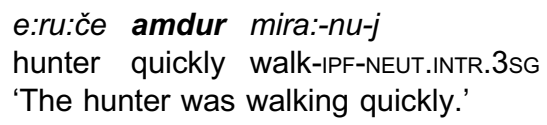

\footnotetext{
${ }^{3}$ The choice between the two variants of the focus marker, $-l \partial(\eta)$ or $-(\partial) k$, depends on the internal structure of the noun phrase and will not be relevant here. Note also that focus marking is absent on 3rd person pronouns, proper names and possessive NPs, but focus agreement on the verb is still obligatory (for details see Maslova, 2003).
} 
(11)

köde mə=law-nu-m, nonyə-lə law-nu-m

person EX=drink-IPF-NEUT.TR.3sg tobacCO-ACC drink-IPF-NEUT.TR.3SG

'the man is drinking, he's drinking tobacco (=smoking).'

The third member of class $\mathrm{X}, m ə(r)=$, is a proclitic, phonologically bound to the verb and represented by two variants, $m ə r=$ before a vowel and $m ə=$ before a consonant.

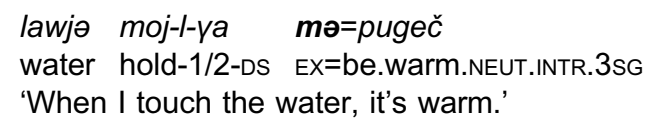

The function of $m \ni(r)=$ has been a matter of some debate, partly similar to the debate concerning the semantics of the Somali verbal particle waa, which has been analysed by various authors as a declarative, predicative, or focus marker (Saeed, 1984: 160ff, 1999: 239ff.; Lecarme, 1999). Krejnovič (1958), who provided the first description of mə(r)=, suggested that it indicates positive polarity; Fortescue (1996) and Kurilov (2006) analyse it as some kind of declarative marker; Maslova (2003: 24) refers to it as an affirmative prefix that signals narrow focus on the verb, whereas in our own earlier work (Matic and Nikolaeva, 2008) we suggested that the function of $m ə(r)=$ is to indicate that the verb is within the focus domain. We will argue in Section 4 that there is a certain truth in all these characterizations, but none of them exhaustively describes the meaning of $m ə(r)=$. As mentioned in the Introduction, the basic conclusion we will make is that $m ə(r)=$ is an existential quantifier, and accordingly we gloss it as $\mathrm{EX}=$ throughout the paper.

What needs to be emphasised at this stage is that $m \partial(r)=$ is, with some minor exceptions, mutually exclusive with regard to other elements of class $\mathrm{X}$ :

$\left(7^{\prime}\right) \quad{ }^{*} m ə t-e k \quad m ə=w e r w ə-I$

I-FOC EX=be.strong-SF

$$
\begin{array}{llll}
\text { *qul'arqa: ma:rqə-n sa:l-ya mə=sayanə-j, } & \text { əl=lukunburəbə-ya } \\
\text { seagull one-ATTR tree-LOC EX=sit-NEUT.INTR.3sG } & \text { NEG=earth-LOC }
\end{array}
$$

$$
\begin{aligned}
& \text { ?? köde nonyə-lə mə=law-nu- } m \\
& \text { person tobacco-ACC EX=drink-IPF-NEUT.TR.3SG }
\end{aligned}
$$

The ungrammatical examples $\left(7^{\prime}\right),\left(9^{\prime}\right)$ and $\left(11^{\prime}\right)$ show that $m ə(r)=$ cannot co-occur with either a non-verbal focus element $\left(\left(7^{\prime}\right)\right.$ and $\left.\left(9^{\prime}\right)\right)$, or a verb modifier $\left(11^{\prime}\right)$. We will return to this point in Section 5.

\subsection{Realis and irrealis clauses}

Before proceeding to investigate the formal properties of class $X$, we will illustrate how the system works by providing a first semantic and formal characterisation of the realis and irrealis in TY.

In our first approximation, the realis meaning comprises non-hypothetical positive assertions (see Sections 4 and 5 for a revised version of this claim). When this interpretation is intended, verb-only clauses are strictly ungrammatical.

*keweč <leave.NEUT.INTR.3sG> intended meaning: 'He left.'

*law-m <drink-NEUT.TR.3sG> intended meaning: 'He drank (it).'

Similarly, realis clauses that only include non-focused non-verbal elements and the verb without $m ə(r)=$, but contain no $\mathrm{X}$, were judged as bad or at best very marginally acceptable by our consultants.

*/? la:mə-lə pa:j-m

dog-ACC hit-NEUT.TR.3SG

intended meaning: 'He hit a dog.'

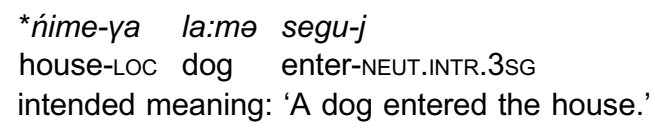




\subsection{Additional evidence for realis: negative polarity/free choice items}

There is independent evidence that the obligatory presence of $X$ has to do with the realis/irrealis distinction which comes from the distribution of negative polarity/free choice items (NP/FCls; TY belongs to the languages that collapse these two categories, see Giannakidou, 2011). In TY NP/FCls are derived from wh-words with the suffixes $-(\eta)$ oll'əlk (on subjects) or -(n)ollan (on objects). Importantly, they are only licit in the clauses that are acceptable without $\mathrm{X}$, as in (23): with negation, in directives, and in clauses encoding hypothetical situations. If $X$ is required, i.e. in positive nonhypothetical assertions, their use is ungrammatical, as in (24), where $m ə(r)=$ and focus agreement block the use of NP/FCls (see Louie, 2008: 108ff. and Bar-el and Denzer-King, 2008: 11 for a similar distribution in Blackfoot).

a. kin-oll'əlk əl=kelu

who-NP/FCI.S NEG=Come(NEG.3SG)

'Nobody came.'

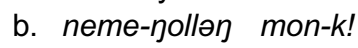

what-NP/FCI.O say-IMP.2sG

'Say anything!' (i.e. don't be silent)

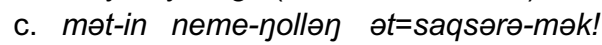

I-DAT what-NP/FCI.O COND=pour-NEUT.TR.2SG

'If you would be so kind to pour me a little bit (sc. in the glass)!'
a. "kin-oll'əlk mə=kelu-j
who-NP/FCI.S EX=COME-NEUT.INTR.3SG

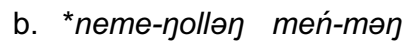
what-NP/FCI.O take-OF.1sG

Examples (23) and (24) show that NP/FCls cannot co-occur with the elements of class X. We do not have enough data for all relevant contexts to judge with confidence whether this is due to their sensitivity to veridicality, i.e. we are not sure whether NP/FCls in TY can only occur in those contexts which do not entail the truth of the proposition, as has been claimed for NP/FCls in many other languages (Giannakidou, 1998, 2011 and other work). What does seem to be obvious is that the distribution of NP/FCls closely follows our realis/irrealis distinction. The explanation at hand is that NP/FCls in TY are referentially deficient in such a way that they cannot introduce discourse referents: in Matthewson's (1998) words, NP/FCls 'fail to positively assert the existence of an entity'. Since they cannot refer, they are licenced only if they are in the scope of an operator that allows for non-existential readings. Negation and the illocutionary and modal operators introduced above are thus the only contexts in which NP/FCls are possible because they do not entail existence (Giannakidou, 2011). This indicates that the presence of X, which blocks NP/FCls, must somehow entail the existence of the referents included in the event denoted by the proposition. At this stage we remain vague as to how exactly the existential import of $X$ comes about. In Sections 4 and 5 we will suggest that this is achieved by unselective existential closure, which constitutes the essence of the TY realis.

Let us summarise the basic distributional data. TY makes a distinction between realis and irrealis realised in the following formal condition: realis clauses must contain at least one element selected from the heterogeneous class which we labelled X, for want of a better term. This class comprises non-verbal foci, verb modifiers and the proclitic $m ə(r)=$. The latter is incompatible with the other two members of the class. Notionally, realis encompasses non-hypothetical positive assertions. On the other hand, negative, non-declarative and hypothetical situations are treated as irrealis. They can or must be encoded without X. Foci and verb modifiers are optional in some of these cases and impossible in others, while $m ə(r)=$ is completely banned from all irrealis clauses. The distribution of NP/FCls corroborates the realis/irrealis dichotomy and confirms that this distinction is related to the entailment of existence in TY. In the following two sections we will analyse the formal and semantic properties of the individual members of the class $X$ in order to explain this peculiar configuration and offer a more precise definition of the meaning of realis in TY. We demonstrate that the elements $X$ do not form a coherent syntactic or semantic class, but are unified at a higher level, that of entailing the existence of the event that matches the proposition.

\section{Non-verbal foci and verb modifiers}

In this section we show that two members of class $X$, non-verbal foci and verb modifiers, display a number of formal similarities, and offer a semantic explanation for this. The particle $m ə(r)=$ differs from them in a number of important ways and will be dealt with separately in Section 4. 


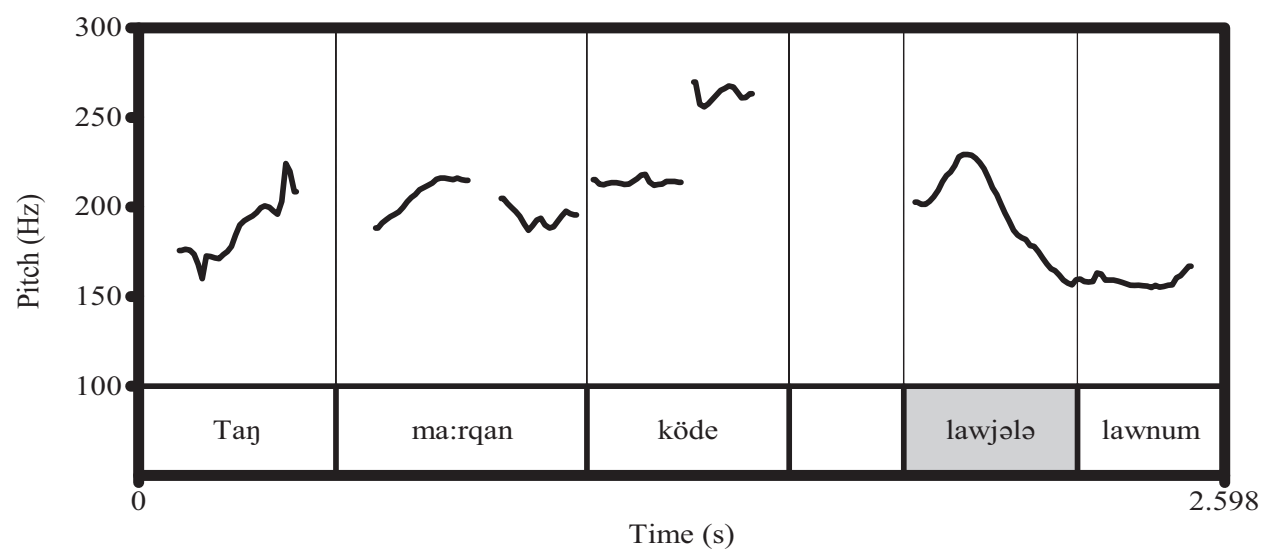

Fig. 2. Contour of (26) with a non-referential nominal (lawjə/ə) in object position.
a. lalimə pude qudo:-tə-j
sledge outside lie-FUT-NEUT.INTR.3sG
'The sledge will lie OUTSIDE.'
b. ${ }^{*} /$ ? pude lalimə qudo:təj.
a. adil
ču:-lə
amdur legu-m
young.man meat-ACC quickly eat-NEUT.TR.3sG
'The young man quickly ate the meat.'
b. *amdur adil ču:lə legum.

The corpus data reveal a slightly more diversified, although not essentially different picture. We have tested the adjacency condition against a corpus consisting of ten TY texts in Maslova (2001), the first five texts from Kurilov (2005), and seven texts recorded by the first-named author. The textual counts are given in Table 1.

Non-referential nominals are immediately preverbal without exceptions. Non-verbal foci and manner adverbs can be separated from the verb, but only in the following cases. First, this occurs when more than one element of class $X$ is present. Non-verbal foci and manner adverbs must precede a non-referential noun, and a non-verbal focus element must precede a manner adverb, as illustrated in (30). That is, if several elements of class $\mathrm{X}$ co-occur, the order is focus-manner adverb-non-referential nominal.

$$
\begin{array}{lllll}
\text { ista:də-yat mit kelu-nu-I, taput mo:rqən } & \text { amutnən lejri:-məク } \\
\text { herd-ABL we come-IPF-NLZR that.FOC only well } & \text { remember-OF.1/2sG }
\end{array}
$$

'How we used to come from the herd, that's the only thing I remember well.'

Second, focus elements and verb modifiers may be separated from the verb by a modal or a focus particle, as in (30) above and in (31). ${ }^{5}$

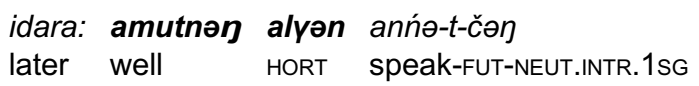

However, such instances are optional and, as the numbers show, fairly rare. The simple generalisation goes as follows: foci and verb modifiers occupy the immediately preverbal position; when they co-occur in the clause, the order is focusverb modifier. A tentative explanation for this order in terms of prominence assignment will be offered in Section 4.2.

\footnotetext{
${ }^{5}$ We have found a few instances in which non-verbal foci are separated from the verb by highly contextually given, mostly pronominal elements (an example, (72), is given in Section 5.2). In one case for which we have a sound recording, the intervening element is fully deaccented. This seems to indicate that the post-focal position of contextually given elements might turn out to be the consequence of optional cliticisation (derived clisis à la Fried, 1999). However, examples are too few to allow for any kind of generalisation, so that this issue remains to be explored when more data are available.
} 
Table 1

Position of the element $\mathrm{X}$ relative to the verb in TY.

\begin{tabular}{lccc}
\hline & Non-V focus & Non-ref N & Manner adverbs \\
\hline Adjacent & $588(97 \%)$ & $68(100 \%)$ & $96(95 \%)$ \\
Non-adjacent & $21(3 \%)$ & 0 & $5(5 \%)$ \\
\hline
\end{tabular}

There are also restrictions on the postverbal position. Although the verb-final syntax of TY is quite rigid, postverbal elements do occasionally occur. They usually have a distinctly topical slant and function as some kind of afterthought, as in many other verb-final languages (see e.g. Erguvanlı, 1984 on Turkish and Butt and King, 1996 on Urdu).
tude-yanə l'e: əl=ičo:
tun köde
he-ACC
PTL NEG=see(NEG.3) this person

(A boy saw a man on the pear tree. He stole the man's basket full of pears.) 'He hadn't seen him, this man.'

But foci, non-referential nouns and manner adverbs can never appear after the verb, as demonstrated in examples (33)-(35). These elicitation judgements are very robust.

*Ma:sa uba:-mələ wadu-ləク

Masha kiss-of. 3 Yukaghir-Foc

intended meaning: 'Masha kissed him, a Yukaghir.'

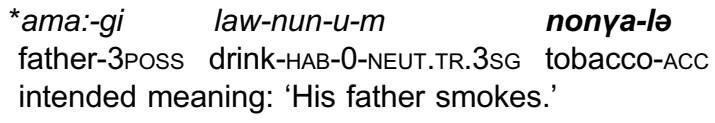
*apanala: jaqtə-j
amutnəク
old.woman sing-NEUT.INTR.3sg well
intended meaning: 'The old woman sings, nicely.'

While providing an analysis of TY clause structure is beyond the scope of this paper, the data cited in this section indicate that non-verbal foci and verb modifiers are associated with the same syntactic position.

\subsubsection{Scope properties}

A further piece of evidence for the claim that verb modifiers and foci share a syntactic position is their behaviour with respect to certain operators. The negative proclitic $ə /=$ operating within a clausal domain can only be attached to the verb or an element X, i.e. focused elements, manner adverbs, and non-referential nouns. Crucially, $ə /=$ is excluded on nonverbal elements that do not belong to class $X$ : for instance, it cannot be hosted by non-focused objects (36b) or nonfocused obliques (37b).
a. раjpə əl=o:-ləク lögitə-mələ
woman NEG=child-FOC feed-OF. 3
'The woman didn't feed the child.'
b. *pajpə əl=0:-lə lögitə woman NEG=child-ACC feed(NEG.3.SG)
a. e:ru:čə əl=a:wjə kelu
hunter NEG=yesterday come(NEG.3.SG)
'The hunter didn't arrive yesterday.'
b. *əl=a:wjə e:ru:čə kelu NEG=yesterday hunter come(NEG.3.SG)

When $ə /=$ is attached to an element of class $\mathrm{X}$, both the narrow and the broad scope readings are available. For example, in (38a), the negation only scopes over the focused object, while in (38b), even though it is technically cliticised 
to the same word, $ə l=$ has a broad reading. Example (39) demonstrates the same ambiguity for negation when $ə /=$ is cliticised to a manner adverb. Crucially, this type of scopal behaviour is attested only for non-verbal foci and verb modifiers, since the negation cannot be attached to other sentence elements (see above).

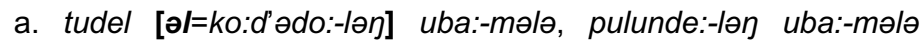
she NEG=boy-FOC kiss-OF.3 old.man-FOC kiss-OF.3

'She didn't kiss a boy, she kissed an old man.'

b. tudel [əl=ko:d'ədo:-ləך uba:-mələ], mo:rqən mər=imid'ə-j she NEG=boy-FOC kiss-OF.3 only EX=dance-NEUT.INTR.3sG 'She didn't kiss a boy, she was just dancing.'

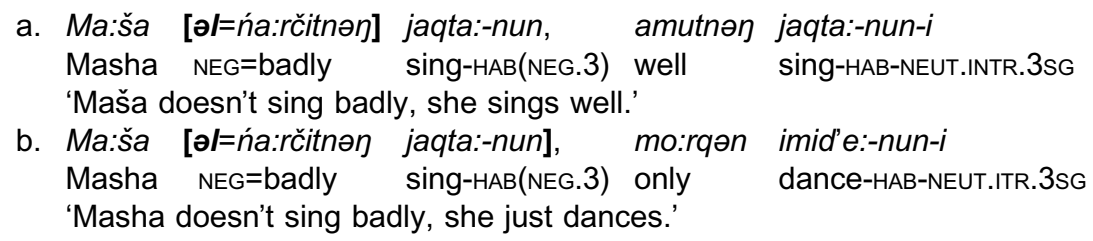

This same scopal ambiguity is observed in relation to the size of focus. Non-verbal focus elements allow for at least two readings, the narrow one, which includes only the focused element, and the broad reading, in which X is integrated into a larger information unit with the material to its right, i.e. the verb. Narrow and broad focus readings are presented in examples (40) and (41) for a focus-marked object; examples (42) and (43) illustrate the same phenomenon with oblique foci, which are not focus-marked in terms of morphology but are immediately preverbal and bear focal intonation.

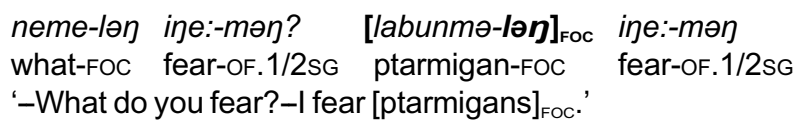

(Kurilov, 2005: 240)
tət či: neme-lə we:-nu-nu-mlə?
you people what-FOC do-IPF-PL-OF.3
Uppul'ə a:wjə [talaw-ləク aji-m/ə] $]_{\mathrm{Foc}}$
Uppul'ə yesterday wild.reindeer-Foc shoot-of.3
'-How's your family doing?-Uppul'e [shot a reindeer $]_{\mathrm{Foc}}$ yesterday.'
qadunudə刀 kewej?
[Moskva-niń $]_{\mathrm{Foc}}$ keweč
whither leave(INTERR.3) Moscow-DAT leave.NEUT.INTR.3sG

'-Where did he go?-He went [to Moscow $]_{\mathrm{Foc}}$.'

araj nunniní-l-ya [Tu:sta: $\chi$-qa kel-l'el-d'en] $]_{\mathrm{Foc}}$

once dream-1/2-DS Tustakh-LOC come-EV-NEUT.INTR.1sG

(beginning of the text) 'I once had a dream: I [arrived at Tustakh] $]_{\text {foc. }}$ '

Manner adverbials behave in the same way, as shown in (44) and (45).

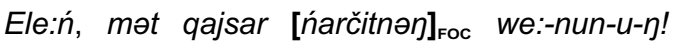

$$
\begin{aligned}
& \text { no I ski badly make-HAB-0-NEUT.TR.1SG }
\end{aligned}
$$

(You're excellent at making skis.) 'No, I make skis [badly] $]_{\mathrm{Foc}}$ !'

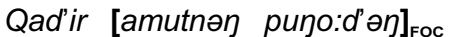

$$
\begin{aligned}
& \text { PTL well rejoice.NEUT.INTR.1SG }
\end{aligned}
$$

(The reindeer came back from the tundra safe.) 'I was [very happy] $]_{\text {Foc. ' }}$

In contrast to these elements of class $\mathrm{X}$, other sentence elements do not display scopal ambiguities. As shown above, non-foci and non-verb modifiers cannot host negation (36b), (37b). They do not produce focus size ambiguities of the kind illustrated above either. For instance, non-focus-marked objects (as opposed to those that carry focus marking, as in (41)) 
can under certain circumstances form a part of a broad focus (ex. (46a); see also (54)), but they can never have a narrow focus reading (46b).
a. [tude tu:ri:-yanə mər=ayarəj-m] $]_{\text {roc }}$. he.Poss trousers-ACC EX=tear-NEUT.TR.3 (He took out one of his traps.) [While doing that,] he tore his trousers.'
b. neme-lə ayarəj-mələ? \# [tu:ri:-yanə] $]_{\text {Foc }}$ mər=ayarəj-m. what-FOC tear-OF. 3 trousers-ACC EX=tear-NEUT.TR.3 (intended reading: 'What did he tear?' 'He tore his trousers.')

In sum, non-verbal foci and verb modifiers share a number of formal properties: they are restricted to the immediately preverbal slot, carry the same prosodic contour, allow for broad and narrow readings, and interact with negation in the same way. This suggests that they occupy a dedicated structural position associated with a particular prosody, and that this position is likely to form a phrasal unit with the verb. The exact syntactic status of this phrase is immaterial for our purposes: what we have sought to show is that these two types of $X$ are to all intents and purposes syntactically and prosodically identical.

\subsection{Prominence and integrated readings}

In this section, we set out to offer an explanation for the apparent syntactic similarity between foci and verb modifiers. Such similarity has been attested in a number of languages, most prominently Hungarian (Kiss, 2002, 2006; Wedgwood, 2005, among others), but also Tatar (Kashaeva, 2012), Turkish (İssever, 2003), and Tamil (Baker, 2012), to mention just a few. Two lines of explanation are discernible, one based on the idea of syntactic incorporation (mostly in the works focusing on non-referential nouns, such as Baker, 2012), the other operating with the notion of focus and/or predication (Wedgwood, 2005; Kiss, 2006). We shall try to unify these two approaches. The last two shared features of foci and verb modifiers we mentioned above, the potential for broad and narrow scopes of the negation, and broad and narrow focus readings, will be instrumental in our explanation.

There is general agreement that foci are placed in the position of maximal prominence (Reinhart, 1995; Zubizaretta, 1998; Büring, 2012, among others), where 'maximal prominence' is to be understood as a morphosyntactically and/or prosodically marked instruction to the hearer that the element in the given position is to be processed with additional attention (cf. Kristensen et al., 2013). It is still debated whether the position of maximal prominence is determined by syntax alone, by prosody or by a combination thereof (see Kučerová and Neeleman, 2012: 6ff. for a recent overview); it is beyond doubt, however, that the location of this position in the clause is a language-specific matter. It has been noted as early as Kim (1988) that head-final languages tend to assign maximal prominence to the syntactic slot immediately preceding the verb. As we saw in the previous section, TY, being a relatively rigid head-final language, conforms to this tendency: the position of maximal prominence is the one adjacent to the finite verb from the left, and it also carries the main sentence stress. This accounts for the placement of narrow non-verbal foci, as in (40): the narrow focus labunmələク ('ptarmigan') must be immediately preverbal because this is the location of maximal prominence. The same holds true for verb modifiers in those rare cases when they alone are focused, as in (44) above. In narrow focus readings, then, nonverbal foci and verb modifiers are immediately preverbal because this is the position that carries the maximal prominence.

Broad focus and other types of broad readings trigger what has been called informational integration (Jacobs, 1999; Büring, 2012): the elements of the broad focus domain are processed as one information chunk and display diminished semantic autonomy. This is parallel to the meaning of verb modifiers, which similarly lack semantic autonomy in the sense that they only are interpretable in relationship to the verb. They therefore need to be interpreted as one informational unit together with the verb. The question is how the simple algorithm of prominent positions described above for narrow focus relates to this kind of integrated interpretation. The approach that has been dominant in the calculation of broad focus in the past decades, focus projection from internal arguments to phrases as defined by Selkirk (1995), has been criticised as being both too powerful and too weak to account for natural language data (Büring, 2006, 2012). Moreover, it is not apt to tackle foci and verb modifiers in a unified way. We therefore adopt a much simpler account, inspired by the constraintbased theory of prominence assignment developed by Büring (2012). Büring proposes an abstract hierarchy of sentence elements, which is meant to account for the "(partial) ordering on categories of morphosyntactic expressions" (Büring, 2012: 29) and predict their syntactic and prosodic behaviour. The basic idea is that the assignment of prominence to an element higher in the hierarchy can trigger a reading in which this element is informationally integrated with an element lower in the hierarchy, but not vice versa: a prominence on the lower element can only result in a narrow focus reading.

What is relevant for our purposes is that arguments count as higher in the hierarchy than predicates. Applied to TY, this means that, when an argument-verb broad focus reading is intended, the argument has to be placed in the position of 
maximal prominence. If the verb itself were placed there (leaving the clause-final structural position empty) and associated with the main sentence stress, the only possible reading would be narrow focus on the verb. For instance, in (41), the predicate and its argument make up the focus domain of the sentence. Since arguments are higher in the hierarchy than predicates, talaw 'wild reindeer' counts as higher ranked than ajimlə 'shot' and is therefore placed in the prominence position. The position of non-verbal foci is thus a corollary of two rules: the language-specific rule of maximal prominence of the preverbal slot, and the more general rule of producing integrated readings by focusing that element of the broad focus domain which is higher in the prominence hierarchy. In the case of narrow foci, it is only the first rule that is at work (47a). With broad foci consisting of an argument and a predicate, both rules conspire and their joint application results in the same structure, as represented in (47b).

a. narrow focus on the argument:

preverbal slot prominence

$\downarrow$

argument in the prominence position

b. broad focus:

$\{$ argument $>$ predicate $\}+$ preverbal slot prominence

$\downarrow$

argument in the prominence position

We argue that the same principle is responsible for the position of verb modifiers. Consider the most conspicuous case first, non-referential nouns that are parts of idioms such as čundə-lə gudiči:- 'think' (thought-Acc put). Being less than fully compositional, this multi-word expression can only be processed as one chunk of information. This implies that its elements have to belong to one and the same focus domain. In order to be processed as one chunk of information, the idiom must conform to the constraints on prominence assignment as described above: the argument-predicate asymmetry places the prominence on the object čundələ. The result is (48a), with an immediately preverbal non-referential noun carrying focus-like prosody. If this constraint is violated and the object is in a position other than immediately before the verb, the result is a non-idiomatic, fully compositional (and usually meaningless) interpretation of the noun-verb complex, as in (48b). ${ }^{6}$
a. mət qo:dəク kelu-l'əl-ni
I how come-EV-NEUT.INTR.3PL thought-ACC put-IPF-NEUT.TR.1SG
'I was thinking about how they arrived.'

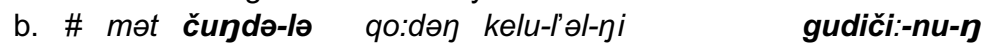
I thought-ACC how come-EV-NEUT.INTR.3PL put-IPF-NEUT.TR.1SG
(resulting reading: 'I put thought about how they arrived.')

The same explanation holds true for all non-referential nominals, not only those that form a part of an idiom. Thus, in a fully compositional noun-verb combination with a non-referential noun such as lawjə-lə law- (water-Acc drink) 'drink water', the integrated reading is achieved by placing the nominal lawjələ in the position of maximal prominence, immediately before the verb. If the noun is moved out of this position, its interpretation can be only referential, usually pertaining to a specific amount of water, and the 'institutionalised activity' reading in the sense of Mithun (1984) is lost.

Thus, non-referential nouns belong to class $X$ because they must be interpreted as one informational unit with the verb; this places them in the same position as non-verbal foci integrated into broad focus domains. Manner adverbs, whose focus-like behaviour in TY was first noticed by Fortescue (1996: 21), conform to the identical type of restriction. Modifiers in TY are incorporated into the ordering of relative strength, such that adverbs are higher in the hierarchy than predicates. Proper manner adverbs and the verbs they modify semantically form a kind of complex predicate: 'to walk fast' is not merely to walk and to be fast at the same time, but rather to perform an action of fast waking, to fast-walk. More technically, the adverb picks out the relevant parameter of the event introduced by the verb and predicates over it (Maienborn and Schäfer, 2011). In other words, manner adverbs and the verbs they modify must be informationally integrated (cf. Eckardt, 2003). Syntactically, this means that manner adverbs must follow the same principles as foci and non-referential nouns.

\footnotetext{
${ }^{6}$ Syntactic flexibility of idioms without concomitant loss of idiomatic readings in languages like English, German or Czech has been amply demonstrated, e.g. in Nunberg et al. (1994) and Fanselow and Lenertová (2011). This seems to be a language-specific matter, as Fanselow and Lenertová (2011: 202-3) themselves note, and it is not quite clear which properties of the language determine this flexibility. In any case, our TY consultants have robust intuitions that examples like (48b) are awkward or simply nonsensical.
} 
If they are narrowly focused, as in (44), they must be in the prominent immediately preverbal position; with an integrated reading, it is the combination of the prominence distribution and the argument/modifier-predicate asymmetry that places them in that same preverbal slot, as illustrated in (39) and (45). Other positions are uniformly judged ungrammatical or at least very strange, as in (29b). In other words, the scheme given in (47) applies to verb modifiers (non-referential nouns and adverbs) in the same way as it applies to non-verbal foci.

This explanation derives the formal similarities of non-verbal foci and verb modifiers from similarities in their meanings. Foci and verb modifiers occupy the position as close to the verb as possible and share a prosodic pattern because they both comply with two rules, the rule of prominent preverbal position and the rule of relative prominence. When narrow focus is intended, only the first rule plays a role; with integrated readings (of which broad focus is a subtype), both of them are relevant. The result is always the same: non-verbal foci and verb modifiers are placed in the immediately preverbal position and must carry a particular intonation contour; in addition, the object located in this position must host the overt focus marker. The ultimate reason why all these elements belong to the same class is thus rooted in information structure: both subclasses are, as it were, inherently focused.

\section{4. mər= and the semantics of realis}

In this section we concentrate on the formal and semantic properties of the final member of class $X$, the particle mər=, and introduce the major semantic characteristics of TY realis. We suggest that by uttering a realis clause, the speaker commits herself to the proposition being true in a certain time span in the actual world or in certain types of preferred worlds.

\subsection{The formal properties of $\mathrm{mə}(\mathrm{r})=$}

The particle $m ə(r)=$ lacks most of the defining formal features of the other two types of $X$, non-verbal foci and verb modifiers. First, it does not display the typical high-low tone followed by a deaccented verb. Instead, it is the verb itself that carries the high-low contour, while the particle does not have a pitch accent of its own (Fig. 3).

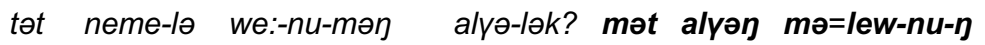

$$
\begin{aligned}
& \text { you what-FOC do-IPF-OF.1/2sG fish-INS I fish EX=eat-IPF-NEUT.TR.1sG } \\
& \text { 'What are you doing with that fish?'-'I'm eating the fish.' }
\end{aligned}
$$

Second, the positional restrictions on $m ə(r)=$ differ from those on the other two members of class $X$. Being a proclitic, it always precedes its host word and belongs to the preverbal clitic cluster together with the negative particle $\partial /=$ and the conditional particle $ə t=$ (see Section 4.2.2 for more detail). Since its host is most commonly the main verb, it might appear that it shares the same position with foci and verb modifiers. However, unlike foci and verb modifiers, $m ə(r)=$ is not restricted to clausal domains: it can also operate over smaller syntactic domains if attached to wh-words. Its meaning in such cases is discussed in Section 4.2.1; here it is only important that it precedes a nonverbal host word, as in (50).

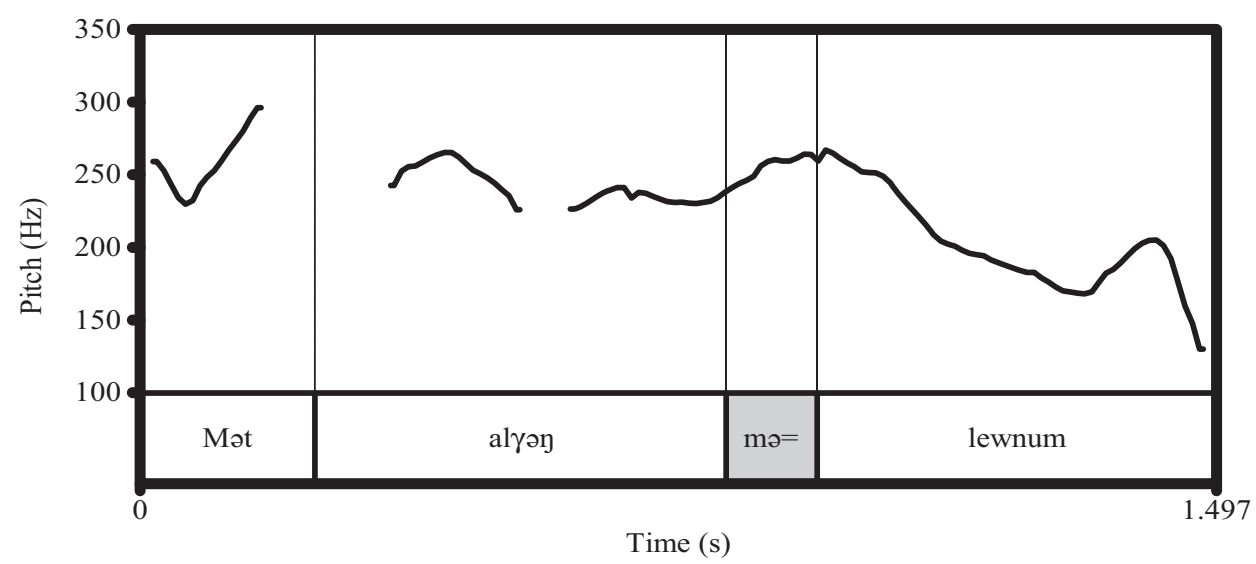

Fig. 3. Contour of (49) with the preverbal particle $m ə(r)=$. 


$$
\text { tan ilen ma:lək mə=pöčeseč, mə=neme we:-rələk }
$$

that reindeer PTL EX=let.go.NEUT.INTR.1PL EX=what do-SS.PF

'We had no choice but to let that reindeer go, after we did something (to it).'

Unlike foci and verb modifiers, $m ə(r)=$ is incompatible with negation and its behaviour with respect to focus size differs from that of the other two relevant classes of expressions (see examples (53)-(55) and the accompanying explanation below).

In short, $m ə(r)=$ does not seem to inhabit the same syntactic position and carry the same type of prosodic prominence as other elements of class $\mathrm{X}$. This suggests that the general scheme of the realis clause proposed in (5), namely $\mathrm{X}+\mathrm{V}$, cannot be derived from a purely structural requirement that the preverbal slot must be filled. The explanation is rather to be sought in the domain of interpretation.

As mentioned in Section 2.1, $m ə(r)=$ has been defined in a number of different, often conflicting ways, none of which seems to be completely wrong or right: it was described as a declarative, affirmative or verb focus marker, and all of these definitions partially cover its uses without being comprehensive. The analysis of $m \ni(r)=$ as an affirmative prefix stems from its incompatibility with negation (51), while the idea that it marks declaratives (as opposed to directives, etc.) is justified by its incompatibility with imperatives (52).

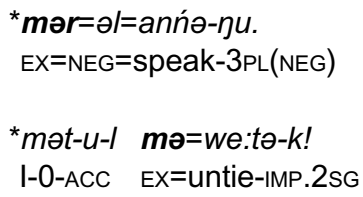

But both explanations fail to describe exhaustively the meaning of $m ə(r)=$. As our examples (18)-(22) show, positive polarity and declarative force are a necessary, but not the sufficient condition for $m \partial(r)=$ to be present. It is also difficult to conceive of a principled reason why a declarative marker would be excluded or optional with modal meanings and negation. The same holds true for the incompatibility of $m ə(r)=$ with other elements of class X, illustrated in $\left(7^{\prime}\right),\left(9^{\prime}\right)$ and $\left(11^{\prime}\right)$ : there is no reason why a declarative or affirmative marker should be banned from clauses with nominal foci or verb modifiers. The attempt to treat $m \ni(r)=$ as a marker of narrow focus on the verb, i.e. as a verbal counterpart of non-verbal foci, is also wrought with empirical problems: sentences with $m ə(r)=$ can contain foci of all sizes, provided no non-verbal element is singled out for focusing, as is apparent in (53)-(55).

$$
\begin{aligned}
& \text { qad'ir mə=jo:yačəli, jo:dəyanə. } \quad \text { e:, } \quad \text { [mə=jo:yačəli }]_{\mathrm{Foc}} \\
& \text { PTL EX=finish.NEUT.INTR.1PL probably INTJ EX=finish.NEUT.INTR.1PL } \\
& \text { '-We're probably done for now. }- \text { Oh yes, we [are done }]_{\mathrm{Foc}} \text { ' }
\end{aligned}
$$

$$
\begin{array}{lll}
\text { Pirkəjəd'-e:-I-niń } & \text { [pude } & \boldsymbol{m} \boldsymbol{m}=\text { pulgeč }]_{\mathrm{Foc}} \\
\text { shamanise-INCH-NLZR-DAT } & \text { outside } & \text { EX=come_out.NEUT.INTR.3SG }
\end{array}
$$

(A shaman was summoned to cure the sick.) 'In order to shamanise, she [went out] $]_{\mathrm{Foc}}$ '. (Maslova, 2001: 31)

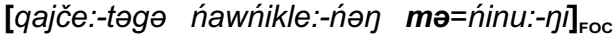

$$
\begin{aligned}
& \text { bear-AUG polar.fOX-COM EX=meet-NEUT.INTR.3PL } \\
& \text { (beginning of a story) '[A bear and a polar fox met }]_{\mathrm{Foc}}
\end{aligned}
$$

The particle $m ə(r)=$ does not express affirmation or declarative force, although its meaning must be somehow related to positive polarity and assertion, and it does not have to be used in order to achieve certain focus readings, as is the case with other members of class $X$. Its obligatory use in realis clauses which do not contain focus elements needs a different kind of explanation.

\subsection{The meaning of $\mathrm{m} ə(\mathrm{r})=$}

We have seen in Section 3.2 that non-verbal foci and verb modifiers are unified by the notions of prominence and informational integration and in this sense ultimately instantiate one category, focus. The semantic contribution of $m ə(r)=$ is the topic of this section. As mentioned in the introduction, there are three meaning components relevant for the TY realis: existential closure, identity of the evaluation world with the actual world, and temporal restrictions. All three are also the relevant elements of the meaning of $m ə(r)=$. We will deal with them one step at a time in what follows. 


\subsubsection{The particle $\mathrm{m} ə(\mathrm{r})=$ as an existential quantifier and indeterminate pro-words}

We propose that $m \partial(r)=$ is an existential operator. When applied to verbs, it binds the event argument and triggers the realis meaning of the sentence; if applied to pronouns, as in (50), it binds the variable in their semantic representation. This existential impact of $m ə(r)=$ is best seen in its application to question words. In this function, illustrated in (50) above, $m ə(r)=$ appears in sub-clausal, individual domains and triggers a specific indefinite interpretation, as the translation of (50) shows (neme 'what', mə=neme 'something (specific)'). This interpretation cannot fall out of the declarative, affirmative or focus meaning of $m ə(r)=$. However, it is easily derived from the existential semantics, as we show in some detail below. Even more interesting is the use of $m ə(r)=$ with so-called question verbs, such as monayər- 'say what', qo:dəl' $ə$ - 'do what', qo:dəgurči:- 'happen what', and qoll'ə- 'be where'.
a. qo:dəgurči:?
what.happen(INTERR.3)
'What happened?'
b. $ə$ l=qo:dəgurči:
NEG=what.happen(NEG.3)
'Nothing happened.'
c. $m \boldsymbol{m}=q o:$ dəgurči: $-j$
EX=what.happen-NEUT.INTR.3SG
'Something happened (but I won't tell you what).'

All question words (pronouns and verbs) in TY invariably behave like qo:dəgurči:- in (56): they have the interrogative interpretation when no proclitic is attached (56a), the negative indefinite reading when combined with the negation $ə l=$ $(56 b)$, and the specific indefinite reading with $m ə(r)=(56 c)$. These variable interpretations qualify them as verbal counterparts of what has been known as 'ignorative' (Wierzbicka, 1980) or 'indeterminate pronouns' (Kratzer and Shimoyama, 2002; Shimoyama, 2006; Gärtner, 2009), i.e. as pro-forms whose sole semantic contribution is to provide variables for quantification. A useful formalisation is proposed by Kratzer and Shimoyama (2002), who treat these proforms as set-denoters. Thus, the denotation of the root qo:dəgurči:- is a set of events without further specification as to their type. Indeterminate pro-words are interpreted via quantification. In the case of the interrogative interpretation (56a), the lack of overt quantification indicates that the meaning of the clause corresponds to the denotation of the verb, modulo temporal anchoring: it is a set of propositions of the form 'there is an event $e$ ', where $e$ is a variable ranging over the contextually determined set of possible predicates describing the event. The result is a set of possible answers, i.e. the Hamblin-style meaning of a question (Hamblin, 1973). Negation in (56b) introduces negative quantification over the set of event variables, so that the sentence means that there is no true proposition of the form 'there is an event $e$ (such that any of the contextually relevant predicates holds true of it)' in the evaluation world. The semantic impact of $m ə(r)=$ in $(56 \mathrm{c})$ is the exact opposite of this, with $m ə(r)=$ quantifying over the set of events and introducing wide scope existential closure over the variable $e$, with the ensuing specific indefinite interpretation: 'there is an event $e$ such that one of the contextually relevant predicates holds true of $e$ in the evaluation world'.

This brings us back to realis clauses. Recall that we provisionally defined the meaning of the TY realis as encoding non-hypothetical positive assertions, which is tantamount to saying that realis is used to encode propositions which the speaker presents as true in the actual world. This definition adds one further condition on the use of $m ə(r)=:$ it existentially quantifies over events that are parts of the actual world, i.e. $m ə(r)=$ is applicable if the evaluation world is the actual world. This, we argue, accounts both for the realis effects of $m ə(r)=$ and for its incompatibility with negation, directives and various hypotheticals, as shown below.

In more technical terms, we can summarise our argumentation up to this point as follows. Applied at the clausal level, the particle $m ə(r)=$ provides an existential closure of the event variable. Denotationally, it is an overt existential quantifier. The application of $m ə(r)=$ to a proposition entails that the proposition is true in the evaluation world specified as the actual world. The existential quantification over events within the actual world can take place only with reference to time, since events take place in time and are defined by it. We shall broach the relationship between $m ə(r)=$ and the temporal structure of events in Section 4.2.3. But before we do that, in Section 4.2.2, we will offer a more precise account of the modal characteristics of $m ə(r)=$ and qualify some of our claims regarding its relationship to hypotheticals.

\subsubsection{Existential semantics of $\mathrm{m} ə(\mathrm{r})=$, restrictions and extensions}

In this section, we argue that the incompatibility or optionality of $m ə(r)=$ with irrealis as described in Sections 2 and 4.1 (negative clauses, directives, and hypotheticals) does not follow from any formal restrictions. Instead it results from the full or partial incompatibility of the existential semantics with the type of content these categories express. 
Negative clauses can never contain $m ə(r)=$ (see example (51) above). One possible explanation would be that $m ə(r)=$ and the negative proclitic $ə=$ cannot co-occur because they compete for the same slot in the preverbal clitic cluster. This syntactic explanation cannot be upheld, since they clearly occupy different positions: $m ə(r)=$ must precede the conditional particle $ə t=$, whereas $ə /=$ follows it.
a. mər=ət=puńi-m
$<E X=C O N D=$ Kill-NEUT.INTR.3SG>
'he would (like to) kill'
b. ət=əl=puńi
$<$ COND $=$ NEG $=$ Kill(NEG.3SG) $>$
'he wouldn't kill'

The explanation therefore must have to do with incompatibility of meanings: $m \ni(r)=$ and the negative proclitic $ə /=$ cannot co-occur in the same clause because negation of the existence of an event stands in contradiction to the existential claim encoded by $m ə(r)=$. What is asserted not to exist cannot be marked as existent. The propositional nature of the negative sentence is ensured via the negative marker itself, not through explicit existential quantification by means of $m ə(r)=($ cf. Zimmermann, 2007; Winter and Zwarts, 2011).

Other irrealis clauses fall under the heading of verbal moods involving possible world semantics. As mentioned in the Introduction, we adopt Kratzer's $(1991,2012)$ modal semantics, whose basic components are the modal base and the ordering source. The modal base is the set of possible worlds relevant for the interpretation of the proposition (e.g. doxastic or epistemic modal base, i.e. the one compatible with what the speaker believes or knows). The ordering source which specifies the partial ordering of worlds according to a relevant criterion determines different modal values. A world can be optimal according to the ordering source for various reasons-e.g. relative to what the speaker desires (buletic), to a particular purpose (teleological), probability (epistemic), etc.

As shown in (52) above, directives cannot host $m ə(r)=$ under any circumstances. The ordering source of directives is buletic, such that worlds are ranked according to the desires of the speaker, the optimal world being the one in which the proposition expressed by the directive sentence comes true. Obviously, at the utterance time, this optimal world is (still) not the actual world. The incompatibility of directives with $m ə(r)=$ naturally falls out from this: it would be semantically incongruous to mark an event which does not hold true in the actual world as existing in that world.

Various types of what we call hypotheticals also mark the proposition as true in one of the possible worlds, without committing the speaker to its truthfulness in the actual world. The lack of a direct relationship to the actual world as the evaluation world allows these clauses to appear without a realis marker, so that they are well-formed without $m ə(r)=$. In actual fact, hypotheticals cannot normally take $m ə(r)=$. This is true of such morphologically derived categories as necessitatives in -morawn'ə- (3c), potentials in -mori- (3b), (21) and conjecturals in -l'əl'tə- (3f), as well as the indicatives co-occurring with hypothetical particles (4b), (22).

There are two exceptions, though: desideratives in -lbuń- (3e), (20) and conditional verb forms preceded by the proclitic $ə t=(3 \mathrm{~d})$. These two categories often occur without $m ə(r)=$, but can nevertheless combine with it. In a corpus consisting of seven texts collected by the first-named author and all texts from Kurilov (2005) and Maslova (2001), there are 143 instances of desideratives in -Ibuń-, $26(18.2 \%)$ of which are combined with $m ə(r)=$. Out of 89 instances of $\partial t=$ hypotheticals, almost a half $(43$, i.e. $48.3 \%)$ have $m ə(r)=$. This might seem to present a challenge to our interpretation of $m ə(r)=$ as existentially quantifying over events in the actual world, as both desired and possible events are clearly not situated in the actual world. However, subtle meaning differences between the desideratives/ conditionals augmented with $m ə(r)=$ and the forms without $m ə(r)=$ indicate how the actual world analysis can be modified to encompass these cases.

Meaning contrasts are more obvious with conditionals. In (58b), the application of $m ə(r)=$ results in a kind of subjectivedesiderative reading of the form in $ə t=$, which otherwise has potential semantics (58a). Readings induced by $m ə(r)=$ vary from the desiderative, as in (58b), to the deontic subjective assessment of possibilities, as in (59). These readings are conventionalised into a polite request type including $m ə(r)=$ and $ə t=$, as in (60). Requests of this kind are responsible for a relatively high percentage of conditional forms marked with $m ə(r)=(25$ out of 43 in our corpus).

a tət amučə brigad'ir ət=nod'ək.

you be.good.PTC foreman COND=be.NEUT.INTR.2sG

'You would be a good foreman.'

b tət amučə brigad'ir mər=ət=nod'ək.

'(I wish/hope that) you (turn out to) be a good foreman.'

id'e: (..) əl=činičərej-dəya mər=ət=qana:-jəク.

now NEG=get.dark-3DS EX=COND=rOam-NEUT.INTR.1SG

'l'd better go now (..), before it gets dark.' 
Va:sjə, mər=ət=kewečək, qo:di:r sayana:-nu-jək?

Vasya $E X=C O N D=$ gO.NEUT.INTR.2SG why sit-IPF-NEUT.INTR.2SG

'Vasya, you should go (you'd better go, I wish you go), why are you still sitting?'

The difference between the potential meaning of the conditional without $m \ni(r)=$ and the interpretations triggered by $m ə(r)=$ seem to boil down to a difference in the ordering source. With bare conditionals, the pre-order of possible worlds in the modal base is either established by a deontic ordering source, or the ordering source is empty, so that the proposition is compatible with the modal base (Kratzer, 1991). This results in a potential reading, and the interpretation is usually that of objective possibility. If $m ə(r)=$ is attached, the interpretation is 'subjective': possible worlds seem to be ranked according to a buletic ordering source within a doxastic or epistemic modal base, so that the best worlds are the ones compatible with the speaker's desires.

The contribution of $m \ni(r)=$ is less tangible with the desiderative in -lbuń-. The intuitions of our consultants are rather tenuous here, and the usual comment is that the form with $m ə(r)=$ is somehow 'stronger', as in (61). Only in one context did we manage to discern an interesting contrast: if the speaker is aware that the desired alternative is not objectively the best one, only the variant without $m ə(r)=$ is felicitous, as in (62). If this contrast between bare forms and forms with $m ə(r)=$ is genuine, then the intuitive difference seems to be similar to that noticed with ət-conditionals: the form with $m ə(r)=$ has a more 'subjective' interpretation.
a. lewdə-Ibuń-i <eat-DES-NEUT.3SG>
b. $m ə=l e w d ə-l b u n ́-i \quad<E X=e a t-D E S-N E U T .3 S G>$
a. mət
I
ado: puńi-Ibuń-i-n.
son kill-DES-0-TR.1SG
'I want to kill my son.'
b. \# met ado: mə=puńilbuńin.

'He wants to eat.'

'He (really) wants to eat.'

It is not immediately obvious how the analysis of $m ə(r)=$ as existential quantifier over events in the actual world is able to capture the usage illustrated in examples (58)-(62): desires belong to the realm of possible worlds and do not hold true in the actual world. One possibility would be to apply the analysis of desideratives according to which they segment the possible continuations of the present into the preferred and dispreferred ones, and state the preferred alternatives (Heim, 1992; Villalta, 2008). The preferred status of the subsequent world in which the proposition turns out to be true may be sufficient to treat it as existent. Situations that are true in the preferred world are more readily conceptualised as true in the actual world than those that are merely possible, necessary or the like. The disadvantage of this analysis is that it cannot explain why $m ə(r)=$ is compatible with the conditional in $\partial t=$ and the desiderative in -lbuń, but not e.g. with the directives, which also divide the worlds into the preferred and dispreferred.

We therefore opt for an enrichment of the standard semantics of mood proposed by Portner and Rubinstein (2012) and adopt the notion of 'contextual commitment'. Commitment is a relationship between an individual (the speaker) and a conversational background (the modal base or the ordering source): as Portner and Rubinstein define it, an individual is committed to a modal base/ordering source if she is prepared to argue for an asserted event within the modal base in a rational way. Applied to the existential semantics of $m \ni(r)=$, the idea of contextual commitment means that only those events to which the speaker is committed can be bound by the existential quantifier and treated as actual world events. The difference in acceptability between (62a) and (62b) thus boils down to the speaker's ability to argue rationally for the event of killing one's own son with respect to a buletic ordering source. The 'subjective', desiderative slant of the conditional in $ə t=$ augmented with $m ə(r)=$, exemplified in (58)-(60), stems from the same source: $m \ni(r)=$ indicates that the speaker commits herself to the ordering source, i.e. to the claim that the asserted event belongs to the best possible worlds according to the given ordering source. The simple potential reading of $ə t=$ without $m \partial(r)=$ indicates the lack of this explicit commitment.

Why is this kind of realis reading adduced by contextual commitment impossible with other moods? There are two possible lines of explanation, a purely semantic one and one based on grammaticalisation. On the semantic account, it can be argued that these moods never fulfil the conditions necessary for contextual commitment proper. For instance, directives imply two participants, the one that demands and the one towards whom the demand is directed. Both of them need to be committed to the modal base for the realis interpretation to be possible; since this is often not the case (see Portner and Rubinstein, 2012), directives do not take $m ə(r)=$. The problem with this kind of analysis is that it cannot account for the rare counterexamples. It is easy to imagine situations where both participants in a directive speech act are committed to the optimal worlds within the modal base, e.g. Bring me the chocolate (so that I can give you a piece of it). However, even in those cases the application of $m ə(r)=$ to the verb is absolutely excluded. This is why we believe that the 
second approach which takes into account diachronic processes is preferable (cf. Mauri and Sansò, 2012b). We contend that the incompatibility of some inflectional moods with realis is fully grammaticalised. The particle $m ə(r)=$ cannot be attached to directives, necessitatives, prospectives, etc., even in those admittedly rare cases in which the conditions for the speaker's contextual commitment are given. The irrealis status of these moods is thus less than fully compositional: the structural marking of the clause as realis or irrealis is dissociated from purely semantic considerations and is thus an automatic consequence of the grammatical mood. The fact that the compositional realis/irrealis distinction is preserved with desideratives and potentials but not elsewhere may have to do with frequency, i.e. with the fact that the conditions for the speaker's contextual commitment are more often fulfilled with these two moods than with other moods. However, given our lack of knowledge of the history of TY, this remains a speculative issue.

What is clear is that the overt existential quantifier in TY applies only to those events which are the highest in rank in the modal base and to which the speaker is committed. They take place in preferred possible worlds and are rationally defensible. This analysis can be extended to the future tense. In TY the realis clauses marked for future must contain an element $\mathrm{X}$, i.e. a non-verbal focus, a verb modifier, or $m \ni(r)=$.

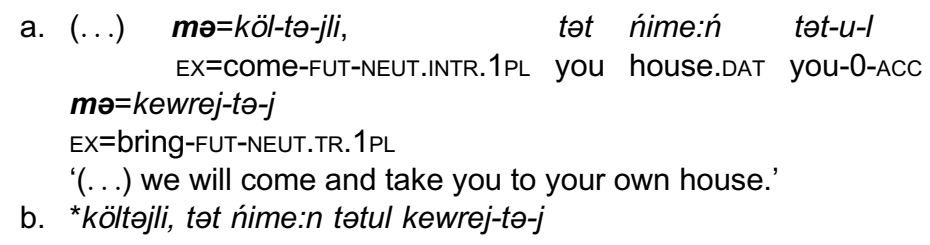

(Kurilov, 2005: 250)

This shows that, if $m \ni(r)=$ is an existential particle with the realis interpretation, the realis category in TY encompasses the future tense. This situation is not uncommon across languages: for instance, in Caddo the TAM system is divided into two superordinate categories, realis and irrealis, and the marker referring to the future co-occurs with the realis set of pronominal affixes (Melnar, 2004). The future tense arguably denotes non-actual events but differs from directives and irrealis hypotheticals in that the latter encode possible continuations of the present, i.e. those non-actual events which may come true, while the future tense expresses all expectable continuations, i.e. non-actual events which are expected to come true in all subsequent worlds (cf. Krifka, 2011). The certainty induced by the universal quantification over future situations implies the same kind of contextual commitment as with desideratives as described above and renders the events expressed by the future tense amenable to existential quantification. ${ }^{7}$

Let us now give an interim summary before proceeding with further intricacies of the semantics of $m ə(r)=$. We have proposed that $m ə(r)=$ encodes existential quantification over the event described by the proposition and thus explicitly marks it as true in the actual world or in the best worlds according to the ordering source to which the speaker is committed. Most restrictions on its use follow naturally from this existential semantics.

\subsubsection{Statives, habituals, and $\mathrm{m} ə(\mathrm{r})=$}

As discussed above, only clauses with irrealis semantics can be well-formed without an element of class X. According to this criterion, stative and habitual predicates in TY count as irrealis. Lexical statives can be marked with the suffix -0:(I)-, while habituals are productively derived with the suffix -nun-. Examples in (64) and (65) contain no non-verbal foci, no verb modifiers and no $m ə(r)=$, and therefore classify as irrealis.

tayo:d'e ńanma-pul oy-o:I-ni

be.dense.PTC willow-PL stand-STAT-NEUT.INTR.3PL

'Willow thickets stood there.'

pure:ク engənə lew-jə köde čundə-gi muńu-mu-nun-i

berry strongly eat-PTC person thought-3POss be.soft-INCH-HAB-NEUT.INTR.3sG

'The mind of a person that has eaten too many berries tends to grow weak.'

(Kurilov, 2005: 280)

The irrealis status of statives/habituals is confirmed by the distribution of negative polarity/free choice items. We have

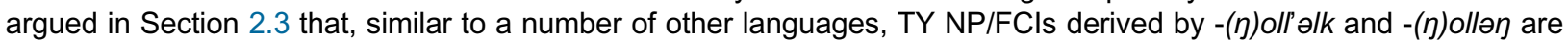
restricted to irrealis contexts. Example (66) shows that they are combinable with statives/habituals.

\footnotetext{
${ }^{7}$ This does not imply that the future tense is universally treated as realis: for instance, in Daakie, as described by Krifka (2011), both future and hypotheticals are treated as irrealis, apparently due to the different direction of grammaticalisation.
} 


\section{kin-oll'əlk aj-nun-u-m}

who-NP/FCI.S shoot-HAB-0-NEUT.TR.3sG

(description of marriage rituals) 'Everybody used to shoot.'

The treatment of stative and habitual predicates as irrealis is not rare across languages. A similar distribution of categories is found in Manam (Lichtenberk, 1983: 187-189), Caddo (Chafe, 1995), Onondaga and other North Iroquoian languages (Chafe, 1995; Alboiu and Barrie, 2010), Yurakaré (van Gijn and Gipper, 2009), Binjin Gun Wok (Evans, 2003: 371ff.), and Bargam (Hepner, 1995). It has often been claimed that 'imperfective' and irrealis are related because of the temporal indeterminacy of both categories (Givón, 1994), their backgrounded status in discourse (Fleischman, 1995), or the incomplete realisation of the event at the reference time (James, 1982). We believe that TY offers a different kind of explanation: that statives/habituals are treated as irrealis has to do with the way events are existentially bound in this language.

We mentioned above that events take place in specific situations, spatiotemporal sections of the world which must be presupposed and temporally delimited (Austin, 1950); it is only within these situations that the specification provided by the sentence holds true. Situations are, among other things, defined by the time they occupy. In order to speak about time, we introduced the distinction between the Topic Time (TT) and the Event Time (ET). Topic Time is the time interval "for which the particular utterance makes an assertion" (Klein, 1994: 37). Thus, it is the time about which the claim is made. Event Time is the time interval in which the event specified by the proposition takes place. The difference between TT and ET is illustrated in the following scenario, adapted from Klein (1994: 41). In the context provided by the question What did you see when you entered the room?, the ET of the sentence $A$ woman opened a window (and then closed it again) corresponds to the time interval of the woman's window opening, while its TT is broader, comprising the whole time covered by the speaker's visual perception after his/her entering the room. ET is contained in TT, as clearly shown by the continuation and then closed it again, which has a separate ET also included into TT.

For most aspectual classes ET is either preferably or obligatorily included into TT, i.e. ET is a subinterval of TT $(E T \leq T T)$. Statives and habituals share one important property: the default relationship between TT and ET runs the other way around. They are the only classes of predicates for which TT is by default a part of ET (TT $\leq$ ET) (see e.g. Smith, 1997). We maintain that the treatment of statives/habituals as irrealis in TY is connected to this property.

Our general claim is that only those propositions that encode eventualities for which ET is contained in TT (ET $\leq$ TT) count as realis in TY. If the time of the event, ET, extends beyond the limits of TT, i.e. if TT $\leq E T$, then one of the possible interpretations is that the proposition is evaluated not only in the actual world, but also in other possible worlds. For instance, if you say The apple is sweet and this is evaluated as true in the here-and-now, this does not necessarily mean that the statement is true in all possible times in all evaluation worlds. The apple could turn sour in one of the possible futures, or it may have been sour before it became ripe. Since the aspectual properties of statives and habituals do not limit ET to a subinterval of TT and thus do not enforce the evaluation of the proposition in the actual/preferred world only, they allow for the irrealis encoding of the events they denote even when their primary reading is that of truthfulness in the actual/ preferred world. This ensures that the unmarked meaning of habituals/statives in TY is irrealis.

However, under special conditions these two aspectual classes can be treated as realis. Let us illustrate this with the following minimal pair:
a. lewej-mən mit-qa ile poj-o:-tə-j
summer-TEMP we-LOC reindeer be.many-STAT-FUT-NEUT.INTR.3SG
'We will have a lot of reindeer in the summer.'
b. lewej-məク mit-qa ile mə=poj-o:-tə-j
summer-TEMP we-LOC reindeer EX=be.many-STAT-FUT-NEUT.INTR.3SG
'We will have more reindeer in the summer.'

In the irrealis version, (67a), the description holds true over a period of time which includes, but is not exhausted by, TT ( $T T \leq E T)$. This means that reindeer will be numerous $(E T)$ in the summer (TT). The evaluation takes place in the actual world, but the speaker does not commit herself to the exact temporal extension of the state: the proposition can be evaluated both after and before TT. This implies that it may be true (or false) both before and after TT. Thus, (67a) is compatible with the situation in which we already have a lot of reindeer and the speaker is just asserting that this will be true in the summer, too. But if the realis construal is chosen, as in (67b), the explicit claim is made that the eventuality exists only within TT (ET $\leq T T$ ), meaning that it is evaluated only in the actual world defined by TT: reindeer will be numerous (ET) only in the summer (TT). The comparative interpretation is an implicature rising out of the interpretation of a temporally limited existence of a state, which is by default interpreted as unlimited. If a state holds true only in TT, then 
there are other times in which the state does not hold true (cf. Klein, 1994: 101ff.), so that (67b) can be meaningfully uttered only if in spring we have fewer reindeer than is planned for the summer.

Comparative implicatures are not the only interpretive effect arising when the realis construal for statives and habituals is chosen. One frequent effect is the implicature of temporariness. The realis example (68a) is interpreted by our consultants as implying that the hero of the story had expected that the yurts had been already removed at TT, the time of looking. In the irrealis construal (68b), this implicature is absent.
a. mə=jö:či:-m tetče:-pə-n ńime-pə mər=oy-o:I-ni
EX=look-NEUT.TR.3SG rich-PL-ATTR yurt-PL EX=stand-STAT-NEUT.INTR.3PL
'He took a look: the rich people's yurts were (still) standing.'
b. mə=jö:či:-m tetče:-pə-n ńime-pə oy-o:I-ni
EX=look-NEUT.TR.3SG rich-PL-ATTR yurt-PL stand-STAT-NEUT.INTR.3PL
'He took a look: (the) rich people's yurts were standing.'

(Kurilov, 2005: 136)

The existentially and temporally bound state in (68a) is interpreted as potentially temporary due to the temporal limitation imposed by $m ə(r)=$ : it is pragmatically meaningful to explicitly bind a state to a specific TT only if there is a reason to point out that the world could have been significantly different at the given TT. If this is not the case, the irrealis construal is sufficient. So the particle $m ə(r)=$ obviously does not merely mark propositions which the speaker presents as true in the evaluation world, where the evaluation world is the actual/preferred world. One further condition is necessary: the existence of the event is explicitly marked by $m ə(r)=$ only if the full temporal extension of this event is contained in the TT. If the temporal extension of the eventuality surpasses the limits of the TT, the irrealis construal is chosen and $m ə(r)=$ is not needed.

The property of mapping ET to TT, which we claim is a part of the semantics of $m ə(r)=$, is aspectual in nature (cf. Klein, 1994). It has been argued that the existential closure over events is performed by aspectual operators, more precisely by the perfective operator (Kratzer, 1998; Beck and von Stechow, 2006). The obvious question then is whether mə(r)= could be defined as an aspectual entity, a perfective marker whose existential import is routinely derived from this more basic meaning. Nothing in our argumentation hinges on the answer to the question whether $m ə(r)=$ is a perfective or an existential operator, as long as we can describe the semantic contribution of $m \ominus(r)=$ as existential closure, be it achieved directly, through existential operator, or indirectly, via some kind of an aspectual operator. However, we prefer to assume the 'pure' existential semantics for $m ə(r)=$, since it is not immediately clear to us how an aspectual meaning would account for such interpretive effects of $m \ni(r)=$ as the specific indefinite readings of indeterminate verbs $(56)$ and non-verbal whwords (50).

\section{3. $T Y$ realis and $\mathrm{mə}(\mathrm{r})=$ : summary}

The analysis of the meaning of $m ə(r)=$ presented above provides us with the full set of conditions a proposition has to fulfil in order to be encoded as realis. As suggested in (2), repeated here as (69), a realis clause in TY denotes an event specified by the proposition, such that the event exists in the actual world or the preferred possible world towards which the event participants have a contextual commitment, within a presupposed situation delimited by the topic time. The particle $m ə(r)=$ contributes existential quantification, i.e. it explicitly marks that the denoted event exists in the actual/ preferred world and that the temporal location of the entire event is within the TT.

$\exists e\left[P(e) \& \operatorname{TIME}(e) \subseteq \mathrm{t}^{\prime} \& \mathrm{e}<\mathrm{w}\right]$
(a) t' $\leq$ TT
(b) $\quad w$ is the actual world or highest ranking world according to the modal base and ordering source
(c) the speaker is contextually committed to the modal base and ordering source.

The use of $m \ni(r)=$ is fully compositional in most cases, i.e. in all those instances in which its application or nonapplication results in a semantic or interpretive difference. The only exception to this is the inflectional moods which are specified as irrealis in grammar, such as directives or necessitatives. So even though there is a semantic basis for this restriction to irrealis, we assume that at least in part it is a product of the individual grammaticalisation processes.

Much more important for our purposes is the question of why explicit existential quantification by means of $m ə(r)=$ is not possible with non-verbal foci and verb modifiers. It is crucial to understand in which way these expressions contribute to the meaning of the sentence so that it can qualify as realis without being marked by an explicit existential quantifier. We attempt to answer this question in the following section, arguing that this distribution is partly ensured by the semantics of focus and partly by inference. 


\section{Focus, verb modifiers and realis}

While it is clear that the existential semantics we propose for $m ə(r)=$ immediately derives the realis meaning suggested in (69), the connection between realis and the other two elements of class $X$, foci and verb modifiers, is far from obvious, as is the reason for the mutual exclusiveness of foci/verb modifiers and $m ə(r)=$. In Section 3, we have shown that focused non-verbal elements and verb modifiers are unified via the category of focus: to all intents and purposes, these two expression types are foci. In our attempt to explain the realis nature of focus in TY, we shall first introduce a semantics for focus and background which is able to capture its existential impact, and then apply it to the TY data.

\subsection{The existential import of focus}

Despite the multiplicity of concepts which the label 'focus' covers and its questionable categorial status (see e.g. Matić and Wedgwood, 2013), it is beyond doubt that many languages have a formal device to indicate the main point of the utterance (Jary, 2010: 129ff.). What is focused is to be understood as the locus of the common ground update (Krifka, 2008). According to the widely accepted Alternative Semantics for focus (Rooth, 1992), the update occurs via invocation of alternatives. While the ordinary semantic value, ignoring the contribution of focus, is a standard proposition, the focus semantic value is a set of propositions that differ from each other only in that the denotatum of the focused expression is replaced by another object of the same type. To constrain the focus semantic value to relevant alternative propositions, a context variable $\mathrm{C}$ is introduced, referring to a contextually determined set of alternatives, along with a focus operator which induces the requirement that $C$ be a subset of focus-induced alternatives. In effect, this creates a set denotation as the background to focus, i.e. a set of contextually relevant propositions. Essentially, this type of semantics for focus is identical to Hamblin's semantics for questions (see Section 4.2.1), according to which the meaning of a question is a set of contextually relevant propositions corresponding to the answer. For instance, the question Who opened the door? and the answer with the focus on the subject, e.g. JoHN opened the door, have an identical focus-semantic value, the set of propositions of the form $x$ opened the door, where $\mathrm{x}$ is a variable over entities constrained by the variable $\mathrm{C}$. The difference between the question and the answer is obviously the identification of one true alternative in the latter. This can be informally represented as follows:

$$
J O H N \text { opened the door } \sim Q \text {, where } C \subseteq Q \text { and } Q \text { is a set of propositions of the form ' } x \text { opened the door' }
$$

The existential import of focus comes from two sources: from the obligatory existential binding of propositions generated by focus semantics and from the default presuppositional interpretation of the disjunctive set $Q$. As mentioned in Section 1, in order to guarantee the propositional nature of sentence denotations, the event variable has to be existentially bound. Thus, if we assume that predicates have event arguments and that focus generates a set of propositions, it follows that these focus-induced propositions have an existential quantifier, i.e. they have the form $\lambda \mathrm{w} \exists e$ $[P(x, e) \& e<w]$. In other words, the semantics of focus generates alternative propositions that already carry existential quantification. The form of the propositions that constitute $Q$ in (70) is thus not merely ' $x$ opened the door', but rather 'there is an event (in a world) such that $x$ opened the door'. Accordingly, (70) has to be modified as follows:

$\left(70^{\prime}\right) J O H N$ opened the door $\sim Q$, where $C \subseteq Q$ and $Q$ is a set of propositions of the form: $\lambda w \exists e[P(o p e n, x, e)$ $\& e<w]$

The second element of the existential import of focus is its relationship to presupposition. Rooth $(1992,1999)$ and many others (e.g. Dryer, 1996; Gawron, 2004; Kratzer, 2004) argue that the background to focus (and to questions) does not involve presuppositions. This implies that $\left(70^{\prime}\right)$ does not presuppose that the event of somebody opening the door took place, i.e. that the question Who opened the door, which is the discourse antecedent of $\left(70^{\prime}\right)$ does not modify the context in such a way that it necessarily entails the truth of the question denotation. The arguments for this are drawn from sentences of the form NoBoDy opened the door, wh-questions modified with if anybody, such as Who, if anybody, opened the door, or question-answer sequences involving conditionals, such as Q: Did someone borrow my racket? A: I don't know, but if JoHN borrowed it, you can forget about getting it back (Gawron, 2004). The background to focus is clearly not existentially presupposed in any of these cases: it is obvious that the interlocutors do not commit themselves to the truth of the event of somebody opening the door or somebody borrowing the racket. The conclusion reached by Rooth and others is that background propositions introduced by focus must somehow find an antecedent in the discourse representation (therefore the $\mathrm{C}$ variable), but they need not be entailed by the current state of the common ground, i.e. be existentially presupposed. 
These arguments seem to be incontestable as far as semantic presupposition is concerned (pace Geurts and van der Sandt, 2004). However, in the vast majority of cases, focusing does result in the background being pragmatically presupposed, i.e. it is as a rule entailed by the global common ground à la Stalnaker, 1974 and by the local information state of interlocutors (Abusch, 2010). Communicatively, it makes sense to ask questions or to assert against a set of background propositions only if at least one member of this set is believed to be entailed by the common ground or easily incorporated into it (see Grice, 1981). In order to account for this we endorse Abusch's (2010) model of soft presupposition triggers, which predicts that all structures that evoke alternative propositions have a potential to serve as presupposition triggers: "[A]though the semantics for focus does not involve an existential presupposition, the semantics for focus does create the potential for a default process to generate a presupposition" (Abusch, 2010: 46). In other words, we assume that the fact that focus evokes alternative propositions and that it is communicatively useful to treat at least one of them as entailed by the common ground leads to presupposing the background to focus by default. There is thus a default interpretive strategy for focus such that, if there are no indications to the contrary (such as conditionals or if any, see above), at least one of the conjuncts in the proposition set Q is treated as true (see Abusch, 2010: 72 for a formal account). We take this to be a generalised conversational implicature (GCI) of focus in the sense of Levinson (2000), i.e. the conventionalised way of interpreting focus which can nevertheless be cancelled if contrary evidence is presented. ${ }^{8}$

What is relevant for our purposes is the consequences of this kind of focus semantics and of the presuppositional GCl for the existential import of focus. We take it that it is necessary for the propositions induced by focus to be existentially bound, i.e. the semantics of focus itself introduces the existential closure over events. The contribution of the presuppositional $\mathrm{GCl}$ is the commitment of the interlocutors to the truth of one of these existentially bound entities: the interlocutors automatically treat one of the background propositions as true in the actual/preferred world, as it is by default interpreted as necessarily following from the common ground.

In actual discourse, background is richer than the simple propositional formula minus focus. One important enrichment is the specification of the Topic Time, TT. Given its context dependency, the background part of the sentence is restricted to the interval about which it is intended to provide specification: if an event is presupposed and under discussion, then the event time is necessarily also the topic time. In the absence of indications to the contrary, the situation defined by the TT is interpreted as an actual world segment (see below). The application of focus thus results in a set of restrictions which are remarkably similar to those defined for the TY realis in (69): the event variable of a focus sentence is existentially bound per default and the event takes place in a presupposed topic time, which identifies the situation, i.e. the relevant section of the world. In the following section, we explore the relevance of this idea for our account of the realis mood in TY.

\subsection{Realis, focus and existential closure in $T Y$}

Armed with the semantics for focus, we now turn to the questions raised above: (a) What is the relationship between focus and the realis mood? (b) Why are foci and verb modifiers, on the one hand, and the particle mə(r)=, on the other, mutually exclusive in TY?

The interpretive mechanism for focus proposed in the previous section gives a straightforward answer to the first question. Propositions induced by focus are existentially bound, and, if no evidence to the contrary is proffered, the background to the focus is interpreted as entailed by the common ground, i.e. presupposed. The event selected to be the non-focus part of the clause is by its nature located in the TT. The entailment of the existence of the event in the TT is by default interpreted as the existence of this event in the actual or a preferred world. These are all properties of the realis mood in TY. The realis interpretation achieved by means of an overt existential quantifier in sentences without non-verbal focus is arrived at via focus semantics and a $\mathrm{GCl}$ in sentences with non-verbal focus.

Does this imply that every sentence containing non-verbal focus (or a verb modifier) automatically counts as realis? The answer is negative. The realis interpretation of focus sentences is at least partly due to a $\mathrm{GCl}$ and, as indicated above, it can be cancelled if evidence to the contrary is given. Thus, if the verb in a sentence with a non-verbal focus carries a marker that indicates any kind of non-realis meaning, this is a sufficient signal that the $\mathrm{GCl}$ is cancelled and the sentence has the appropriate irrealis reading, as in (71).

\footnotetext{
${ }^{8}$ One of the poster examples for the non-semantic nature of focus presuppositions, sentences of the type NOBODY came, cannot be expressed

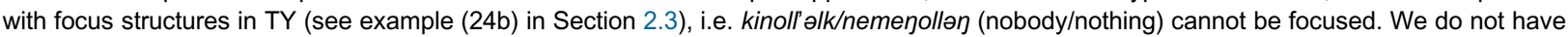
other arguments against the presupposed nature of background in TY, but this might imply that the focus structures in TY actually carry stronger presuppositional conditions than their European counterparts (see Matthewson, 2006 for cross-linguistic variation of presuppositional marking).
} 
tanut ət=meń-məク.

this.FOC COND=take-OF. $1 / 2 \mathrm{sG}$

'This is what I would take.'

In other words, if a sentence contains focus or a verb modifier, it receives the realis interpretation by default, which is sufficient for it to appear without the overt existential quantifier $m ə(r)=$. If the background contains indications that the evaluation world is not the actual/preferred world, the $\mathrm{GCl}$ does not apply anymore and the sentence is irrealis.

The question about the mutual incompatibility of non-verbal focus elements and $m ə(r)=$ is more complex. Recall that there are no purely structural reasons for the incompatibility of $m ə(r)=$ with non-verbal foci and verb modifiers. As we have shown in Section 4.1, they do not compete for the same syntactic position: $m ə(r)=$ belongs to the preverbal clitic cluster and is inseparable from the verb, while other elements of class $X$ are not. In those rare instances where the focus element is not immediately preverbal, but separated from the verb by a contextually given element (cf. footnote 6), focus is still incompatible with $m \ni(r)=$, as illustrated in $(72)$ and its ungrammatical version $\left(72^{\prime}\right)$ (square brackets indicate the element intervening between the focus and the verb).

köde-n kedejo-k [tittə a:ri:] su:sej-nu-l man-ATTR majority-FOC 3PL.POSS bow throw-PL-SF

("Those who are against me should throw away their bows.") 'And most of the men threw away their bows.'

(Kurilov, 2005: 156)

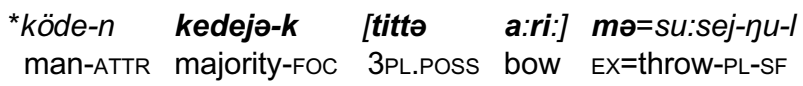

It is examples like $\left(72^{\prime}\right)$ that provide substantial evidence for the claim that the reason why $m ə(r)=$ is incompatible with non-verbal foci is semantic rather than syntactic in nature.

The best way to define the contexts where $m ə(r)=$ appears is to employ a negative definition: $m ə(r)=$ is used when no non-verbal element of the proposition is discourse-prominent enough to be focus-marked and no verb modifier is present. The complementary distribution of focus and $m ə(r)=$ can be seen as a direct consequence of their relationship to existential quantification. If focus is applied, the event variable is existentially bound and the realis meaning is achieved via implication that at least one of the background propositions is entailed by the common ground and true in the actual world. The addition of $m ə(r)=$ would achieve the same effect with different means, by direct existential quantification, and would in effect do the same job, i.e. provide existential closure of the event variable, as the focus. This would contravene the linguistic economy principles, and we contend that this is the reason $m ə(r)=$ is incompatible with focus. In other words, the particle $m ə(r)=$ is a last resort solution to overtly close the event variable. It is employed in those realis sentences where the alternative means for existentially closing the variable fail.

This leaves us with the last remaining puzzle: why is a last resort solution such as $m ə(r)=$ necessary at all, i.e. why do events need to be overtly marked as existent in TY? If focus ensures that events are existentially closed, then one would expect that, in the absence of non-verbal foci, a focus on the verb should be able to do the same, i.e. to bind the event variable and allow for different sizes of focus (i.e. at least those that are shown in (53) through (55)) without any explicit marking. This is obviously not the case: the existential marker $m ə(r)=$ is obligatory when non-verbal foci are absent and the focus is on the verb.

We have no ready-made explanation for this puzzle. One possibility might be that the existential closure must be encoded via either focus/verb modifiers or $m \ni(r)=$ because its position has to be overtly signalled. We have shown in Sections 2 and 3 that in TY this is achieved via a number of formal signals which obey certain rules of prominence assignment: syntactic position, morphological marking, and prosody. But the verb in TY is defective in the sense that it lacks the special marking other types of foci display. This may be taken to imply that the verb in TY cannot send the formal signal necessary for the recognition of the locus of existential closure and, in the final consequence, for the construction of a realis clause. The corollary of this explanation would be that an alternative way of encoding the existential closure is needed: the dedicated existential operator $m ə(r)=$. We find this line of explanation promising, but the reader should be aware of its conjectural nature: at our current stage of knowledge of the TY grammar and the way it is processed, we lack sound arguments to support it.

\section{Conclusion}

This paper has shown that Tundra Yukaghir has a category of realis which at first sight appears to be an instance of Portner's $(2009,2011)$ notional mood, as it is realised syntactically (and partly prosodically) rather than by means of 
inflection. The realis in TY denotes the events in the actual world including future events and optionally desideratives, while the irrealis comprises potential actualisations (a range of epistemic, deontic and intentional meanings) and nonactualizations (counterfactual and negative constructions, i.e. the realm of the unrealised), as well as habituals/statives. The realis clause must contain a syntactic element selected from a closed class: a non-verbal focus, a verb modifier, or the participle $m ə(r)=$. On a closer look, this class decomposes into two sub-classes: on the one hand, non-verbal foci and verb modifiers, which inhabit the preverbal position, and on the other hand, the particle $m ə(r)=$, which is a part of the preverbal clitic cluster and forms a single phonological word with the verb. Non-verbal foci and verb modifiers are not only formally similar; they also instantiate, to all intents and purposes, the same semantic entity which we label 'focus'. In contrast, the particle $m ə(r)=$ functions as an existential operator. Despite the fact that these two sub-classes belong to different semantic domains and are formally distinct, their distributional properties suggest that they form a kind of paradigm in the structure of the TY clause: they are in complementary distribution. In other words, if a focus or a verb modifier is present in a realis clause, $m \ni(r)=$ is excluded; if they are not present, $m ə(r)=$ becomes obligatory. We have further argued that nonverbal foci and $m \partial(r)=$ are used in the same types of contexts, namely, those that refer to the actual world in the Topic Time, and make essentially the same semantic contribution, providing the existential closure of the event variable. We believe that this result may add two new dimensions to the realis/irrealis debate.

First, within the opposition realis vs. irrealis, the latter is formally and functionally unmarked in TY. Realis in this language is associated with a single meaningful contribution which must be overtly expressed, while irrealis is the default category: the clause must be interpreted as irrealis in the absence of the marker of realis. This is quite a surprising result given that realis is the mood of main assertions. However, there are formal parallels in other languages: for instance, in Teiwa (Papuan) irrealis has no overt expression, while realis is signalled by a morphological marker (Klamer, 2012). From a function viewpoint, we find at least partial parallels in some analyses of the subjunctive. ${ }^{9}$ There are suggestions in the literature that within the opposition indicative vs. subjunctive, the subjunctive is actually a semantic default, i.e. it has no semantics of its own or has a vacuous semantics. This idea (which, however, did not remain without critique, see e.g. the contributions in Quer, 2009) was explored by Portner (1997), Schlenker (2005) and Marques (2009), who argue that the Romance subjunctive occurs in those contexts in which the indicative is inappropriate. This suggests that the environments in which the subjunctive/irrealis appears do not necessarily form a natural class even within a single language, and raises the question of a particular licensing condition for the indicative/realis instead. In other words, the relevant typological question may not be 'what is the semantics of the irrealis?' but rather 'what is the semantics of the realis?', and this is what we have explored in this paper (cf. Portner and Rubinstein, 2012).

Note that the indicative in the European languages is used both in the independent function and in a wide range of embedded contexts, while the TY realis occurs exclusively in independent clauses. This has a bearing on the nature of the licensing condition. Schlenker (2005), for instance, suggests that the indicative triggers a presupposition on the value of a world term, indicating that the world $w$ lies in the Context Set of individual $x^{\prime}$ at time $t^{\prime}$ in world $w^{\prime}$. This means that the (dependent) indicative expresses commitment but not necessarily on the part of the speaker: it may well be another individual introduced in the higher clause. Giannakidou's $(1998,2011)$ notion of veridicality, which lies at the centre of her analysis of the Modern Greek subjunctive, is also relativised with respect to the epistemic agent. In contrast, we have argued that the TY realis denotes an event that exists in the actual world as evaluated solely by the speaker. Thus, both the realis and indicative mark an assertive act but they differ in terms of the epistemic model with which it may be associated, apparently due to different syntactic environments.

The second issue raised by our analysis relates to the kind of category the TY realis instantiates. As discussed in Section 1, a number of authors share the view that the opposition between realis and irrealis boils down to a conglomerate of language-specific categories that have similar extensions. The underlying assumption here is that linguistic categories are entities, things among other things, which are unmistakably essentialist in nature. The common identity condition for a category is that a certain formal feature directly encodes a certain (array of) meaning(s). This equally applies to inflectional categories and the categories of meaning such as the notional mood: a meaning component, modality, is directly encoded by a formal feature, except that this feature is not necessarily inflectional. Moreover, in the frameworks which Van Valin and La Polla (1997: 8) call 'syntactocentric' the determination of the notional mood depends on the syntactic presence of one relevant element: the embedding predicate or a property of the complementiser system such as some kind of (covert) modal operator, a feature, or a functional category.

Our description of the mood system in TY defies definition in terms of essences. The notional feature that defines the realis/irrealis dichotomy in TY is the existential closure within the Topic Time. If an eventuality can be interpreted as an existentially closed segment of the Topic Time, it counts as realis, if not, it is irrealis. However, we proposed that the nature of this property is interpretation-based. Two distinct grammatical entities, the preverbal focus and the existential particle,

\footnotetext{
${ }^{9}$ The subjunctive is often claimed to encode the same functional domain as the irrealis, while the difference between them can partly be attributed to different grammatical traditions, see e.g. Palmer (2001) and Timberlake (2007).
} 
are included in one single paradigm due to the existential import they both have, even though this import is directly encoded in one case $(m \partial(r)=)$, while in the other (foci, verb modifiers), it comes about indirectly, in interpretation. Since the existential effects of both focus and $m ə(r)=$ result in the interpretation which has to do with the choice of the evaluation world, limiting it to the actual world, this interpretive category squarely falls into the category of mood. Indeed, it has the typical extension of a regular realis: there are cross-linguistic parallels even for such relatively rare phenomena as the optional inclusion of desideratives and the exclusion of statives and habituals from the domain of realis. So realis in TY is not a discrete denotation, but a combination of two different denotations, focus and the existential quantifier, that are in complementary distribution due to the identical interpretive effects they produce. In some sense, then, this result confirms the hypothesis that the grammatical patterns involving unrealised states of affairs and, consequently, the realis/irrealis distinction, are actually based on other notions (Bybee, 1998; Bybee et al., 1994).

On a more general note, our analysis shows that what at first sight appears to be a simple denotation (realis) cannot be taken at its face value. On closer inspection, it turns out that the purported simple denotation is not a discrete category at all, but is composed of two source denotations instead, existential and focal, which are only unified into one category at the level of pragmatically enriched interpretations. It is in this sense that languages might exhibit categories that cannot be conceived of as essences, but are rather to be formalised as a set of identical meaningful effects. The current controversy about the universality of linguistic categories (Hauser et al., 2002; Everett, 2005; Nevins et al., 2009; Evans and Levinson, 2009; Haspelmath, 2010, to name just a few) might profit from differentiating between essentialist, Platonic categories, which do not appear to stand a good chance of being universal, and the interpretative categories like TY realis, which may well turn out to be detectable across languages, minor or major variation notwithstanding (see Matić and Wedgwood, 2013 for a similar position). Cases like the TY realis are a clear warning against reification of perceived meanings and an even clearer call to take the difference between encoded and inferred meanings seriously in the analysis of linguistic categories, both within and across languages.

\section{Acknowledgments}

We presented the ideas incorporated in this paper at the Workshop on Predicate Focus (Potsdam 2008), at LAGB 50 (Edinburgh 2009), at the Linguistic Institute, University of Colorado (Boulder 2011), at Humboldt University Berlin (2012), at the University of Potsdam (2013) and in the Surrey Morphology Group (2014); the input we received there has modified the way we have analysed our data. The paper has greatly profited from the discussions we had with Daniel Hole, Robert Van Valin and Cecilia Odé. Their help is gratefully acknowledged. We also thank Lingua's anonymous reviewers, who made many valuable comments which significantly helped us to improve the paper. The fieldwork on TY conducted in 2008-2012 (Dejan Matić) and 2011 (Irina Nikolaeva) was supported by the Max Planck Society and the VolkswagenStiftung. Our thanks go to our Yukaghir language consultants: Maria Kurilova, Matrena Tokhtosova, Svetlana Atlasova, Gavril Kurilov, Anna Tret'jakova, Il'ja Kurilov and, most of all, to Vasilij Tret'jakov, whose profound knowledge of TY has made the work on this language such a pleasurable experience. All errors remain our own.

\section{References}

Abusch, D., 2010. Presupposition triggering from alternatives. J. Semant. 27, 37-80.

Alboiu, G., Barrie, M., 2010. Expanding on aspect in Onondaga. In: Annual Meeting of the Canadian Linguistic Association. Concordia University, Montreal, QC. http://www.yorku.ca/galboiu/documents/CLA_2010handout.pdf

Austin, J.L., 1950. Truth. In: Proceedings of the Aristotelian Society, Supp. vol. XXIV Reprinted in Philosophical Papers. Oxford University Press, Oxford, pp. 117-133.

Baker, M., 2012. Pseudo-Noun Incorporation as Covert Noun Incorporation: Linearization and Crosslinguistic Variation. MS. Rutgers University. http://www.rci.rutgers.edu/ mabaker/papersupdate.html

Bar-el, L., Denzer-King, R., 2008. Irrealis in blackfoot? In: Proceedings of the 11th Annual Workshop on American Indigenous Languages (Santa Barbara Papers in Linguistics 19), pp. 3-14.

Beck, S., von Stechow, A., 2006. LFS für Ereignissemantik. MS. University of Tübingen.

Büring, D., 2006. Focus projection and default prominence. In: Molnár, V., Winkler, S. (Eds.), The Architecture of Focus. Mouton De Gruyter, Berlin, pp. 321-346.

Büring, D., 2012. Predicate integration: phrase structure or argument structure? In: Kučerová, I., Neeleman, A. (Eds.), Contrasts and Positions in Information Structure. Cambridge University Press, Cambridge, pp. 27-47.

Butt, M., Holloway King, T., 1996. Structural topic and focus without movement. In: Butt, M., Holloway King, T. (Eds.), On-line Proceedings of the LFG96 Conference http://www.stanford.edu/group/cslipublications/cslipublications/LFG/1/toc-lfg1.html

Bybee, J., 1998. Irrealis as a grammatical category. Anthropol. Linguist. 40, 257-271.

Bybee, J., Perkins, R., Pagliuca, W., 1994. The Evolution of Grammar. University of Chicago Press, Chicago.

Chafe, W., 1995. The Realis-Irrealis distinction in Caddo, the Northern Iroquoian languages, and English. In: Bybee, J., Fleischman, S. (Eds.) Modality in Grammar and Discourse. Benjamins, Amsterdam, pp. 349-365.

Comrie, B., 1992. Focus in Yukaghir (Tundra dialect). In: Aronson, H.I. (Ed.), The Non-Slavic Languages of the USSR. Chicago Linguistic Society, Chicago, pp. 55-70. 
Cristofaro, S., 2012. Descriptive notions vs. grammatical categories: unrealized states of affairs and 'irrealis'? Lang. Sci. 34, 131-146(special issue on "What do languages encode when they encode reality status?" guest editors Mauri, C., Sansò, A.).

Davidson, D., 1967. The logical form of action sentences. In: Rescher, N. (Ed.), The Logic of Decision and Action. University of Pittsburgh, Pittsburgh, pp. 81-95.

De Haan, F., 2012. Irrealis: fact or fiction? Lang. Sci. 34, 107-130(special issue on What do languages encode when they encode reality status? guest editors Mauri, C., Sansò, A.).

Dryer, M., 1996. Focus, pragmatic presupposition, and activated propositions. J. Pragmat. 26, 475-523.

Eckardt, R., 2003. Manner adverbs and information structure: evidence from the adverbial modification of verbs of creation. In: Lang, E., FabriziusHansen, C., Maienborn, C. (Eds.), The Grammar of Adjuncts. Mouton de Gruyter, Berlin, pp. 61-306.

Elliott, J.R., 2000. Realis and irrealis: forms and concepts of the grammaticalisation of reality. Linguist. Typol. 4, 55-90.

Erguvanlı, E.E., 1984. The Function of Word Order in Turkish Grammar. University of California Press, Berkeley.

Evans, N., 2003. Bininj Gun-wok: A Pan-dialectal Grammar of Mayali, Kunwinjku and Kune. Pacific Linguistics, Canberra.

Evans, N., Levinson, St., 2009. The myth of language universals: language diversity and its importance for cognitive science. Behav. Brain Sci. 32 (5), 429-492.

Everett, D.L., 2005. Cultural constraints on grammar and cognition in Pirahã. Curr. Anthropol. 46, 621-646.

Fanselow, G., Lenertová, D., 2011. Left-peripheral focus: mismatches between syntax and information structure. Nat. Lang. Linguist. Theor. 29, 169-209.

Fleischman, S., 1995. Imperfective and Irrealis. In: Bybee, J., Fleischman, S. (Eds.), Modality in Grammar and Discourse. Benjamins, Amsterdam, pp. 519-552.

Foley, W.A., Van Valin Jr., R.D., 1984. Functional Syntax and Universal Grammar. Cambridge University Press, Cambridge.

Fortescue, M., 1996. Grammaticalized focus in Yukagir: is it really grammaticalized and is it really focus? In: Engberg-Pedersen, E., et al. (Eds.), Content, Expression and Structure: Studies in Danish Functional Grammar. Benjamins, Amsterdam, pp. 17-38.

Fortescue, M., 1998. Language Relations across Bering Strait: Reappraising the Archaeological and Linguistic Evidence. Cassell, London \& New York.

Fried, M., 1999. Inherent vs. derived clisis: evidence from Czech proclitics. J. Linguist. 35, 43-64.

Gärtner, H.-M., 2009. More on the indefinite-interrogative affinity: the view from embedded non-finite interrogatives. Linguist. Typol. 13, 1-37.

Gawron, J.M., 2004. Accommodation and propositional focus. Theor. Linguist. 30, 87-97.

Geurts, B., van der Sandt, R., 2004. Interpreting focus. Theor. Linguist. 30, 1-44.

Giannakidou, A., 1998. Polarity Sensitivity as (Non)veridical Dependency. Benjamins, Amsterdam \& Philadelphia.

Giannakidou, A., 2011. Positive polarity items and negative polarity items: variation, licensing, and compositionality. In: Maienborn, C., von Heusinger, K., Portner, P. (Eds.), Semantics: An International Handbook of Natural Language Meaning, vol. 2, Mouton de Gruyter, Berlin, pp. 1660-1712.

Givón, T., 1994. Irrealis and the subjunctive. Stud. Lang. 18, 265-337.

Grice, P., 1981. Presupposition and conversational implicature. In: Cole, P. (Ed.), Radical Pragmatics. Academic Press, New York, pp. $183-198$.

Hamblin, Ch., 1973. Questions in Montague English. Found. Lang. 10, 41-53.

Haspelmath, M., 2010. Comparative concepts and descriptive categories in cross-linguistic studies. Language 86, 663-687.

Hauser, M.D., Chomsky, N., Tecumseh Fitch, W., 2002. The faculty of language: what is it, who has it and how did it evolve? Science 298, 15691579.

Heim, I., 1992. Presupposition projection and the semantics of attitude verbs. J. Semant. 9, 183-221.

Hepner, M., 1995. Tense, aspect, and modality in Bargam. Lang. Linguist. Melanesia 26, 1-31.

Isssever, S., 2003. Information structure in Turkish: the word order - prosody interface. Lingua 113, 1025-1053.

Jacobs, J., 1999. Informational autonomy. In: Bosch, P., van der Sandt, R. (Eds.), Focus. Linguistic, Cognitive, and Computational Perspectives. Cambridge University Press, Cambridge, pp. 56-81.

James, D., 1982. Past tense and hypothetical. Stud. Lang. 6, 375-403.

Jary, M., 2010. Assertion. Palgrave Macmillan, Houndsville.

Kashaeva, G., 2012. The Tatar IP-field. Gener. Gramm. Geneva 8, 77-94.

Kim, A.-H.O., 1988. Preverbal focusing and type XXIII languages. In: Hammond, M., Moravcsik, E., Wirth, J. (Eds.), Studies in Syntactic Typology. Benjamins, Amsterdam, pp. 147-169.

Kiss, K.É., 2002. The Syntax of Hungarian. Cambridge University Press, Cambridge.

Kiss, K.É., 2006. Focussing as predication. In: Molnar, V., Winkler, S. (Eds.), The Architecture of Focus. Mouton de Gruyter, Berlin, pp. $169-193$.

Klamer, M., 2012. Reality status in Teiwa (Papuan). Lang. Sci. 34, 216-228.

Klein, W., 1994. Time in Language. Routledge, London \& New York.

Koopman, H., Szabolcsi, A., 2000. Verbal Complexes. MIT Press, Cambridge, MA.

Kratzer, A., 1991. Modality. In: von Stechow, A., Wunderlich, D. (Eds.), Semantik/Semantics: An International Handbook of Contemporary Research. De Gruyter, Berlin, pp. 639-650.

Kratzer, A., 1998. More structural analogies between pronouns and tenses. In: Strolovich, D., Lawson, A. (Eds.), Proceedings of SALT 8. CLC Publications, Cornell University, Ithaca, pp. 92-110.

Kratzer, A., 2004. Interpreting focus: presupposed or expressive meanings. Theor. Linguist. 30, 123-136.

Kratzer, A., 2012. Modals and Conditionals. Oxford University Press, Oxford.

Kratzer, A., Shimoyama, J., 2002. Indeterminate pronouns: the view from Japanese. In: Otsu, Y. (Ed.), Proceedings of the 3rd Tokyo Conference on Psycholinguistics. Hituzi Syobo, Tokyo, pp. 1-25.

Krejnovič, E.A., 1958. Jukagirskij Jazyk. Nauka, Moscow \& Leningrad.

Krejnovič, E.A., 1982. Issledovanija i Materialy Po Jukagirskomu Jazyku. Nauka, Leningrad.

Krifka, M., 1989. Nominal reference, temporal constitution and quantification in event semantics. In: Bartsch, R., van Benthem, J., von Emde Boas, P. (Eds.), Semantics and Contextual Expression. Foris Publication, Dordrecht, pp. 75-115.

Krifka, M., 2008. Basic notions of information structure. Acta Linguist. Hung. 55, 243-276. 
Krifka, M., 2011. Notes on Daakie (Port Vato): sounds and modality. In: Clemens, L.E., Scontras, G., Polinsky, M. (Eds.), Proceedings of the Eighteenth Meeting of the Austronesian Formal Linguistics Association (AFLA). Harvard, pp. 46-65. http://westernlinguistics.ca/afla/ proceedings/afla18/

Kristensen, L.B., Wang, L., Petersson, K.M., Hagoort, P., 2013. The interface between language and attention: prosodic focus marking recruits a general attention network in spoken language comprehension. Cereb. Cortex 23, 1836-1848.

Kučerová, I., Neeleman, A., 2012. Introduction. In: Kučerová, I., Neeleman, A. (Eds.), Contrasts and Positions in Information Structure. Cambridge University Press, Cambridge, pp. 2-25.

Kurilov, G.N., 2005. Fol'klor Jukagirov. Nauka, Moscow \& Novosibirsk.

Kurilov, G.N., 2006. Sovremennyj Jukagirskij Jazyk. Ministerstvo obrazovanija RS(Ja)/IPMNS, Jakutsk.

Lecarme, J., 1999. Focus in Somali. In: Rebuschi, G., Tuller, L. (Eds.), The Grammar of Focus. Benjamins, Amsterdam, pp. 275-309.

Levinson, S., 2000. Presumptive Meanings. MIT Press, Cambridge, MA.

Lichtenberk, F., 1983. A Grammar of Manam. University of Hawaii Press, Honolulu.

Louie, M., 2008. A Temporal Anchoring of Individuals, Events and Sub-events in Blackfoot. MA thesis. University of Toronto. http://www.individual. utoronto.ca/mlouie/MLOUIE-2008-MA.pdf

Maienborn, C., 2011. Event semantics. In: Maienborn, C., von Heusinger, K., Portner, P. (Eds.), Semantics: An International Handbook of Natura Language Meaning, vol. 1, Mouton de Gruyter, Berlin, pp. 802-829.

Maienborn, C., Schäfer, M., 2011. Adverbs and adverbials. In: Maienborn, C., von Heusinger, K., Portner, P. (Eds.), Semantics: An International Handbook of Natural Language Meaning, vol. 2, Mouton de Gruyter, Berlin, pp. 1390-1420.

Marques, R., 2009. On the selection of mood in complement clauses. In: Hogeweg, L., de Hoop, H., Malchukov, A. (Eds.), Cross-linguistic Semantics of Tense, Aspect, and Modality. Benjamins, Amsterdam, pp. 179-204.

Maslova, E., 2001. Yukaghir Texts. Harrassowitz, Wiesbaden.

Maslova, E., 2003. Tundra Yukaghir. LINCOM Europa, München.

Maslova, E., 2005. Information structure in Tundra Yukaghir and typology of focus structures. In: Fernandez-Vest, J. (Ed.), Les Langues Ouraliennes Aujourd'hui. Honoré Champion, Paris, pp. 599-610.

Maslova, E., 2006. Information focus in relational clause structure. In: Tsunoda, T., Kageyama, T. (Eds.), Voice and Grammatical Relations: In Honor of Masayoshi Shibatani. Benjamins, Amsterdam, pp. 175-194.

Matić, D., Nikolaeva, I., 2008. Predicate focus and the particle mə(r)= in Tundra Yukaghir. November 2008In: Paper Delivered at Predicate Focus Workshop. University of Potsdam.

Matić, D., Odé, C., in press. On prosodic signalling of focus in Tundra Yukaghir. Acta Linguist. Petropolit.

Matić, D., Wedgwood, D., 2013. The meanings of focus: the significance of an interpretation-based category in cross-linguistic analysis. J. Linguist. 49, 127-163.

Matthewson, L., 1998. Determiner Systems and Quantificational Strategies: Evidence from Salish. Holland Academic Graphics, The Hague.

Matthewson, L., 2006. Presupposition and cross-linguistic variation. Proc. NELS 37, 63-76.

Mauri, C., Sansò, A., 2012a. What do languages encode when they encode reality status? Lang. Sci. 34, 96-106(introduction to the special issue "What do languages encode when they encode reality status?" guest editors Mauri, C., Sansò, A.).

Mauri, C., Sansò, A., 2012b. The reality status of directives and its coding across languages. Lang. Sci. (Special issue on "What do languages code when they code realisness?" guest-editors Mauri, C., Sansò, A.).

McGregor, W., Wagner, T., 2006. The semantics and pragmatics of irrealis mood in Nyulnyulan languages. Oceanic Linguist. 45, 339-379.

Melnar, L.R., 2004. Caddo Verb Morphology. University of Nebraska Press, Lincoln.

Mithun, M., 1984. The evolution of noun incorporation. Language 60, 847-894.

Mithun, M., 1995. The Relativity of Irrealis. In: Bybee, J., Fleischman, S. (Eds.), Modality in Grammar and Discourse. Benjamins, Amsterdam, pp. 367-388.

Nevins, A., Pesetsky, D., Rodrigues, C., 2009. Pirahã exceptionality: a reassessment. Language 85, 355-404.

Nikolaeva, I., 2000. Chrestomathia Yukagirica. ELTE, Budapest.

Nikolaeva, I., 2006. A Historical Dictionary of Yukaghir. Mouton de Gruyter, Berlin.

Nunberg, G., Sag, I.A., Wasow, T., 1994. Idioms. Language 70, 491-538.

Palmer, F., 2001. Mood and Modality. Cambridge University Press, Cambridge.

Portner, P., 1997. The semantics of mood, complementation, and conversational force. Nat. Lang. Semant. 5, $167-212$.

Portner, P., 1999. The semantics of mood. Glot Int. 4 (1), 3-9.

Portner, P., 2009. Modality. Oxford University Press, Oxford.

Portner, P., 2011. Verbal mood. In: Maienborn, C., von Heusinger, K., Portner, P. (Eds.), Semantics: An International Handbook of Natural Language Meaning, vol. 2, Mouton de Gruyter, Berlin, pp. 1262-1291.

Portner, P., Rubinstein, A., 2012. Mood and contextual commitment. In: Chereches, A. (Ed.), Proceedings of SALT 22. CLC Publications, Cornell University, Ithaca, pp. 461-487.

Quer, J. (Ed.), 2009. Twists of Mood: The Distribution and Interpretation of Indicative and Subjunctive. Special issue of Lingua 119.

Reinhart, T., 1995. Interface Strategies. OTS Working Papers. Utrecht University, Utrecht.

Rooth, M., 1992. A theory of focus interpretation. Nat. Lang. Semant. 1, 75-116.

Rooth, M., 1999. Association with focus or association with presupposition. In: Bosch, P., van der Sandt, R. (Eds.), Focus: Linguistic, Cognitive and Computational Perspectives. Cambridge University Press, Cambridge, pp. 232-244.

Saeed, J.I., 1984. The Syntax of Focus and Topic in Somali. Helmut Buske Verlag, Hamburg.

Saeed, J.I., 1999. Somali. John Benjamins, Amsterdam.

Schlenker, P., 2005. The Lazy Frenchman's approach to the subjunctive (speculations on reference to worlds, presuppositions, and semantic defaults in the analysis of mood). In: Geerts, T., van Ginneken, I., Jacobs, H. (Eds.), Romance Languages and Linguistic Theory 2003 Benjamins, Amsterdam, pp. 269-309.

Selkirk, E., 1995. Sentence prosody: intonation, stress, and phrasing. In: Goldsmith, J.A. (Ed.), The Handbook of Phonological Theory. Blackwell, Cambridge, MA, pp. 550-569. 
Shimoyama, J., 2006. Indeterminate phrase quantification in Japanese. Nat. Lang. Semant. 14, 139-173.

Smith, C., 1997. The Parameter of Aspect. Kluwer, Dordrecht.

Stalnaker, R., 1974. Pragmatic presuppositions. In: Munity, M., Unger, P. (Eds.), Semantics and Philosophy. New York University Press, New York, pp. 197-214.

Timberlake, A., 2007. Aspect, tense, mood. In: Shopen, T. (Ed.), Language Typology and Syntactic Description, vol. 3, Cambridge University Press, Cambridge, pp. 280-333.

Van Gijn, R., Gipper, S., 2009. Irrealis in Yurakaré and other languages: on the cross-linguistic consistency of an elusive category. In: Hogeweg, L., De Hoop, H., Malchukov, A. (Eds.), Cross-linguistic Semantics of Tense, Aspect, and Modality. Benjamins, Amsterdam, pp. 155-178. Van Valin, R.D., La Polla, R.J., 1997. Syntax. Structure, Meaning and Function. Cambridge University Press, Cambridge.

Verstraete, J.-C., 2005. The semantics and pragmatics of composite mood marking: the non-Pama-Nyungan languages of Northern Australia. Linguist. Typol. 9 (2), 223-268.

Villalta, E., 2008. Mood and gradability: an investigation of the subjunctive mood in Spanish. Linguist. Philos. 31, 467-522.

Wedgwood, D., 2005. Shifting the Focus: From Static Structures to the Dynamics of Interpretation. Elsevier, Oxford.

Wierzbicka, A., 1980. Lingua Mentalis: The Semantics of Natural Language. Academic Press, Sydney.

Winter, Y., Zwarts, J., 2011. Event semantics and abstract categorical grammar. In: Kanazawa, M., Kornai, A., Kracht, M., Seki, H. (Eds.), Mathematics of Language, vol. 12, Springer, Berlin, pp. 174-191.

Zimmermann, M., 2007. Overt existential closure in Bura (Central Chadic). In: Friedman, T., Gibson, M. (Eds.), SALT XVII. Cornell University, Ithaca, NY, pp. 333-350.

Zubizaretta, M.L., 1998. Prosody, Focus, and Word Order. MIT Press, Cambridge, MA. 